\title{
Industry Expertise of Independent Directors and Board Monitoring
}

\author{
Cong Wang, Fei Xie, and Min Zhu*
}

\begin{abstract}
We examine whether the industry expertise of independent directors affects board monitoring effectiveness. We find that the presence of independent directors with industry experience on a firm's audit committee significantly curtails firms' earnings management. In addition, a greater representation of independent directors with industry expertise on a firm's compensation committee reduces chief executive officer (CEO) excess compensation, and a greater presence of such directors on the full board increases the CEO turnoverperformance sensitivity and improves acquirer returns from diversifying acquisitions. Overall, the evidence is consistent with the hypothesis that having relevant industry expertise enhances independent directors' ability to perform their monitoring function.
\end{abstract}

\section{Introduction}

The board of directors, as an integral element of a firm's corporate governance system, performs the dual role of monitoring and advising top management (Adams and Ferreira (2007), Harris and Raviv (2008), and Adams, Hermalin, and Weisbach (2010)). Whereas all directors can contribute to the advisory function, the monitoring duty mostly falls to independent directors. Not surprisingly, improving board independence was a major emphasis of the corporate governance reforms and regulations following high-profile corporate scandals in the early 2000s. Much of the academic literature on corporate boards also focuses on director independence and its effects on firm performance and decision making. ${ }^{1}$ Although independence determines directors' monitoring incentive and is a necessary condition for boards' effective oversight of management, what also matters is whether independent directors have the capability to perform their monitoring duty. Yet, research on the issue of director capability has been scarce,

\footnotetext{
*Wang (corresponding author), congwang@baf.cuhk.edu.hk, Chinese University of Hong Kong, CUHK Business School, Shatin, Hong Kong; Xie, xief@udel.edu, University of Delaware, Lerner College of Business and Economics, Newark, DE 19716; and Zhu, minzhu@ cityu.edu.hk, City University of Hong Kong, College of Business, Kowloon Tong, Hong Kong. We thank Jarrad Harford (the editor) and an anonymous referee for comments that significantly improved the paper. We also thank seminar participants at the Chinese University of Hong Kong and Clemson University for helpful suggestions. Wang and Xie acknowledge the financial support from the National Nature Science Foundation of China (NSFC-71272221 and NSFC-71102076).

${ }^{1}$ See Hermalin and Weisbach (2003) and Adams et al. (2010) for surveys of this literature.
} 
with notable exceptions being studies examining the implications of independent directors having financial and accounting expertise (e.g., Agrawal and Chadha (2005), Guner, Malmendier, and Tate (2008)). The public policy interest in this issue also intensified after the recent global financial crisis, as both academics and policymakers questioned to what extent the qualifications (or the lack thereof) of independent directors were responsible for the failure of corporate governance at many financial institutions. In this paper, we aim to fill the void in the literature by investigating a potential source of independent director monitoring capabilities. Specifically, we examine whether a firm's board monitoring effectiveness is related to the extent to which independent directors have prior experience in the firm's industry.

Although director industry experience clearly has the potential to influence the functioning of boards, whether it can actually enhance board monitoring effectiveness is difficult to predict ex ante. During the 2008-2009 financial crisis, the issue of independent directors' industry expertise was brought to the forefront of the discussion on corporate governance and corporate boards in particular. For example, it was reported that before its enormous write-downs of mortgagerelated asset value, Citigroup did not have a single independent director on its board who had extensive experience in the banking and finance sector. ${ }^{2}$ In the aftermath of the significant losses, Citigroup announced plans to add directors with "expertise in finance and investment" to its board. This anecdote suggests that independent directors experienced in the industry in which a firm operates are potentially more effective monitors because their industry expertise enables them to better understand the firm's unique challenges and opportunities, analyze any information pertinent to the firm's operation and financial conditions, and ultimately evaluate the decision making by the firm's managers. ${ }^{3}$ We term this conjecture as the "expert monitor" hypothesis. Given the potential value that director industry experience may bring, the presence of industry expert directors on the boards of large U.S. corporations appears low. In a sample of Standard \& Poor's (S\&P) 500 companies during the period of 2000-2007, we find that the average proportion of independent directors with relevant industry experience is about $25 \%$.

On the other hand, prior experience in a firm's industry may potentially reduce the degree of effective separation between independent directors and firm management, because they may have common friends and acquaintances from within the industry, belong to the same social circle for work-related reasons (e.g., industry conventions or trade shows), or have crossed paths in their careers. Sharing similar experience with management can also make independent directors more sympathetic to the challenges and difficulties facing managers, and thus more lenient in their monitoring efforts. To the extent that director independence is compromised by prior experience in the firm's industry, the presence of

\footnotetext{
${ }^{2}$ See Eric Dash, "Dean of Harvard Business School May Join Citigroup's Board," New York Times (July 9, 2008).

${ }^{3}$ These advantages can also make independent directors with relevant industry experience capable of providing higher-quality advisory service to management. Our analysis of firm acquisition decisions in Section IV provides some evidence in this regard.
} 
independent directors with industry experience may weaken the intensity of board oversight and lead to more opportunistic behavior by managers. We term this conjecture as the "compromised monitor" hypothesis.

We first evaluate the two competing hypotheses in the context of one of the board's most important responsibilities, that is, its oversight of corporate financial reporting. Although we also examine board monitoring in such key tasks as designing executive compensation packages, curtailing managers' empire-building attempts, and disciplining poorly performing chief executive officers (CEOs), we focus on board oversight of financial reporting for two reasons. First, a failure by boards to apply effective control over firms' financial reporting process can result in poor disclosure quality and, worse, financial misrepresentation. Poor-quality disclosure obfuscates firms' true performance and increases the difficulties and costs that outside investors face in evaluating managerial decision making and reducing private benefits consumption. Financial misconduct, as an extreme form of poor-quality financial reporting, often causes substantial shareholder losses upon revelation (Karpoff, Lee, and Martin (2008)). Not surprisingly, improving financial reporting quality is a top priority for lawmakers and regulators in their efforts to strengthen corporate governance through legislation and regulations. For example, the Sarbanes-Oxley Act (SOX) and related regulatory changes include specific requirements on the independence of and the presence of financial expertise on firms' audit committees. Therefore, it is of great policy interest to see whether other aspects of director characteristics, such as industry expertise, can also strengthen a board's monitoring effectiveness over financial reporting quality.

Second, independent directors themselves also suffer reputational damages and adverse labor market consequences when the firms on whose boards they sit are involved in financial misrepresentation. Fich and Shivdasani (2007) and Srinivasan (2005) find that outside directors of firms committing financial misconduct or restating earnings experience significant declines in the number of other board seats they hold. To the extent that directors value the pecuniary benefits (cash and equity pay) and nonpecuniary benefits (prestige, status, and connections) associated with outside board memberships, this ex post settling up by the director labor market provides powerful incentives for independent directors to be vigilant about their firms' financial reporting. However, whether they are capable of doing so and what factors potentially make them capable remain unclear. ${ }^{4}$

We answer these questions by investigating whether the presence of industryexpert independent directors (IEDs) on corporate boards is related to the extent of a firm's earnings management behavior. Earnings management is one manifestation of the agency conflicts between managers and shareholders. Prior studies show that managers are able to extract various types of private benefits and

\footnotetext{
${ }^{4}$ Aside from incentive and capability, a separate but important issue is whether boards and audit committees have enough opportunities to review and monitor firms' financial reporting and curtail earnings management. To shed light on this issue, we examine the frequency of audit committee meetings. We find that they meet quite often, averaging close to nine meetings per year (median: eight meetings per year) in a random sample of 100 S\&P 500 firms during our sample period. Therefore, audit committee members appear to have ample opportunities to detect and reduce firms' earnings management if they have the incentives and expertise to do so.
} 
personal gains by manipulating reported financial results (e.g., Perry and Williams (1994), Bergstresser and Philippon (2006)). Aggressive earnings management can lead to financial misrepresentation that, upon discovery, causes substantial shareholder value losses and results in earnings restatements, shareholder lawsuits, and/or regulatory sanctions (e.g., Dechow, Sloan, and Sweeney (1996), Karpoff et al. (2008)). Based on the expert monitor hypothesis, we expect a greater presence of IEDs to enhance board monitoring capability and reduce earnings management. Industry expertise is critical for independent directors to fulfill their financial reporting oversight responsibility because a significant portion of a firm's financial reporting practice is driven by operations and economic conditions specific to its industry. Dichev, Graham, Harvey, and Rajgopal (2013) point out that it is difficult for outsiders to detect earnings manipulations, but large deviations from industry and peer firm practice can serve as a red flag for potential financial misreporting. Therefore, a sufficient understanding of the industry is crucial for evaluating the many aspects of financial reporting, such as revenue recognition, expense classification, discretionary expenditure, and asset write-downs. The compromised monitor hypothesis, on the other hand, predicts that the presence of more IEDs may weaken the monitoring incentive of boards and allow more aggressive earnings management by managers.

Our analysis of a sample of firms that were part of the S\&P 500 index during the period from 2000 to 2007 yields evidence consistent with the expert monitor hypothesis. Specifically, we follow prior studies (e.g., Jones (1991), Dechow et al. (1996), Bergstresser and Philippon (2006), and Hazarika, Karpoff, and Nahata (2012)) and use the absolute value of abnormal accruals to measure earnings management. Our choice is driven by the observation in Dichev et al. (2013) that it is difficult for outsiders to uncover earnings manipulation, and the observation that large unexplained accruals are often indicative of underlying financial misrepresentation. Therefore, outside directors on boards and audit committees may focus on abnormal accruals in their efforts to monitor corporate financial reporting and prevent financial misconduct. Earnings management through accruals can be either within generally accepted accounting principles (GAAP) or in violation of GAAP. The reputation and labor market considerations mentioned earlier will make independent directors averse to both within-GAAP and GAAP-violating earnings management, because often there is only a fine line separating the two types of earnings management activities, and it is difficult for independent directors sitting on audit committees to determine whether firms have crossed it or not. In addition, even within-GAAP earnings management activities, if carried out too aggressively, may increase the risk of GAAP violation and trigger the reputational and labor market penalties for independent directors.

Following Kothari, Leone, and Wasley (2005) and Gong, Louis, and Sun (2008), we adjust the abnormal accruals for firm performance. We find that the percentage of a firm's independent directors on the audit committee who have prior experience from the firm's industry is significantly and negatively associated with performance-adjusted abnormal accruals. This evidence holds while we control for a wide array of observable firm characteristics, as well as unobservable time-invariant firm attributes through firm fixed effects. In contrast, untabulated results show that a greater presence of IEDs on the full board is only 
insignificantly related to less earnings management. This finding accentuates the importance of focusing on audit committees in the current context, because they are directly in charge of overseeing corporate financial reporting.

We next extend the earnings management analysis to examine whether the industry expertise of independent directors can reduce the occurrence of financial misrepresentation, which can result from aggressive earnings management. We find that a greater percentage of IEDs on the audit committee is associated with a significantly lower likelihood of intentional financial misreporting. This evidence is robust to using both an ex ante measure of a firm's probability of committing material financial misstatements (Dechow, Ge, Larson, and Sloan (2011)) and the ex post incidence of irregularity/material accounting restatements (Hennes, Leone, and Miller (2008)). These results echo our findings from the accruals earnings management analysis and lend further support to the expert monitor hypothesis.

As additional evidence for the expert monitor hypothesis, we document several cross-sectional variations in the effect of independent director industry experience on the accruals-based earnings management and probability of material financial misstatements. Specifically, the significantly negative effect of audit committee industry experience is mostly concentrated in i) firms from more homogeneous industries, where the experience obtained from one firm is more easily transferable and applicable to another firm; ii) firms with greater information asymmetry, where there is more potential for managers to engage in opportunistic behavior and where relevant industry experience is more crucial for independent directors to understand and evaluate the firm's financial reporting; iii) firms where CEOs have greater incentives to manipulate earnings as a result of their equitybased compensation; and iv) firms associated with a larger magnitude of abnormal accruals, where the risk of violating GAAP and committing financial misreporting is higher. Finally, we find that independent director industry experience is more effective in reducing earnings management and the probability of financial misreporting if the industry experience was obtained more recently, from working for public firms, at the executive level, and from finance- and accounting-related roles.

A typical concern for corporate governance research is the endogeneity or omitted-variable problem. Our study is no exception. Even though we control for firm fixed effects in our model specifications, it remains possible that some time-varying firm attributes uncontrolled for in our regressions are correlated with both independent director industry experience and earnings management. We directly address the endogeneity concern by performing 2-stage least-square (2SLS) regressions in which we introduce a geography- and industry-based instrumental variable for the presence of independent directors with industry experience. Specifically, for each firm, the instrumental variable is specified as the number of other companies with which the firm shares the same first 3 digits of the zip code of the corporate headquarters location and the same 2-digit Standard Industrial Classification (SIC) code but not the same 4-digit SIC code. This variable is intended to capture the potential supply of local director candidates with relevant industry experience and is based on the following stylized facts about the director-firm matching process: i) there is a strong local component 
to the director labor market, in the sense that director candidates are more likely to join geographically proximate firms (Knyazeva, Knyazeva, and Masulis (2013)); ii) executive experience is a typical background for outside directors (Linck, Netter, and Yang (2008)); and iii) firms are unlikely to invite executives from direct competitors to serve on their boards. We expect that firms located close to a larger number of noncompeting industry peers are more likely to have a greater presence of independent directors with relevant industry experience. This notion is confirmed by the first-stage estimation results of our 2SLS regressions. More important, the second-stage results indicate that firms with a greater presence of IEDs on the audit committee are associated with significantly less abnormal accruals and a lower likelihood of committing financial misreporting, even after correcting for endogeneity.

In addition to examining firms' earnings management in a general setting, we also investigate whether the presence of IEDs can curb firms' earnings management behavior before major corporate events. Previous studies find that firms tend to manage their earnings upward through positive accruals prior to seasoned equity offerings (SEOs) and downward through negative accruals prior to open-market stock repurchases. Our analysis reported in Internet Appendix C (available at www.jfqa.org) indicates that firms with a larger percentage of IEDs on their audit committees display fewer instances of both earnings management tendencies.

Finally, we examine whether industry expertise enhances the board's monitoring effectiveness and alleviates agency problems in other aspects of firm policies. We consider three areas where board monitoring is especially important: CEO compensation, CEO turnover decisions, and corporate acquisitions. We find that a greater presence of IEDs on corporate boards is associated with significantly lower excess CEO compensation and higher CEO turnover-performance sensitivity, with the first result based on measuring IED presence at the level of compensation committees. In terms of firm acquisition decisions, we find that the acquiring firm's independent director experience in the target's industry improves acquirer returns in diversifying acquisitions, which often represent managers' empire-building attempts and destroy shareholder value (Morck, Shleifer, and Vishny (1990)).

Our study makes several contributions to the literature. First, we shed light on the broad question of what determines independent director effectiveness by focusing on a previously underexplored dimension of board structure, that is, the presence of independent directors with relevant industry experience. We investigate the implications of independent director industry experience for board monitoring effectiveness, and find evidence consistent with an expert monitor hypothesis. Specifically, a higher percentage of independent directors on the audit committee with relevant industry experience enhances board oversight of corporate financial reporting, thereby limiting managers' earnings management behavior and reducing the probability of financial misstatements. In addition, the presence of more industry expert independent directors on boards is also associated with lower excess CEO compensation, higher CEO turnover-performance sensitivity, and better diversifying acquisition performance. By highlighting the importance of independent directors' capability to perform their monitoring 
function, we complement prior studies of corporate boards that focus on the incentives of directors to monitor managers.

In its focus on director industry expertise, our paper is related to the works of Fernandes and Fich (2012) and Minton, Taillard, and Williamson (2011), both of which examine the relation between the financial experience of banks' outside directors and banks' risk and performance leading up to and during the credit crisis. We, on the other hand, study a large cross section of firms spanning a broad range of industries. In addition, we evaluate the effectiveness of boards in fulfilling their key responsibilities, including corporate financial reporting, CEO compensation, CEO turnover, and corporate acquisitions.

Our study is also related to Dass, Kini, Nanda, Onal, and Wang (2014), as both papers investigate the importance of board industry expertise. But the types of industry expertise examined by the two studies are different. Dass et al. examine director experience from a firm's upstream (supplier) or downstream (customer) industries and focus on experience gained from public firms, whereas we examine director experience from the firm's own industry and include experience gained from both public and private firms in that industry. We also explore cross-sectional variations in the directors' industry expertise, for example, whether directors obtained the experience more recently, from working for a public or private company, and from serving in the capacity of a firm's executives (insiders) or outside directors. In addition, although it is not an explicit objective of Dass et al. to distinguish between the monitoring and advisory roles of boards, and their findings are consistent with both functions, we focus on areas of corporate policy and decision making in which board monitoring is more important, and show that independent directors' industry expertise improves board monitoring. Nevertheless, the two separate investigations provide complementary evidence suggesting that director expertise from both a firm's related industries and own industry can improve the effectiveness of corporate boards.

We also contribute to the literature on the effect of board structure on financial reporting quality. Prior studies examine either the independence of boards and audit committees (e.g., Klein (2002)) or the presence of financial or accounting experts on boards and audit committees (e.g., Agrawal and Chadha (2005), DeFond, Hann, and Hu (2005), Krishnan and Visvanathan (2008), and Dhaliwal, Naiker, and Navissi (2010)). Our results suggest that whether independent directors have relevant industry experience is another important determinant of their effectiveness in monitoring firms' financial reporting processes. In addition, we provide evidence on the types of firms that benefit from independent director industry expertise and the types of industry experience that can enhance independent directors' monitoring effectiveness.

The remainder of the paper is organized as follows: Section II describes the procedures for sample construction and presents summary statistics of the sample. Section III analyzes the effects of independent director industry experience on accrual-based earnings management, the ex ante probability of financial misstatement, and the ex post incidence of earnings restatements. Section IV reports the results on whether independent director industry expertise affects CEO compensation, CEO turnover, and acquisition performance. Section V concludes. 


\section{Sample}

\section{A. Sample Construction}

We start with the universe of firms that were part of the S\&P 500 index during the years 2000-2007. We focus on independent directors because inside and gray directors are often subject to conflicts of interest and cannot be relied upon to carry out a board's monitoring function. We collect information on the career paths of independent directors of S\&P 500 firms using the BoardEx database. ${ }^{5}$ The BoardEx employment file reports detailed information on directors' employment histories, including the names of their employers, their roles in the organizations that they have worked for, and the years of their employment. We focus on past director and executive-level positions, because lower-level roles (e.g., rank-and-file employee, trainee) are unlikely to provide an individual the platform and opportunity to gain sufficient knowledge and understanding about a firm and its industry. The positions we consider include director, CEO, chief financial officer (CFO), chief operating officer (COO), chairman, president, vice president, manager, chief officer, owner, division $\mathrm{CEO}$, division chairman, division $\mathrm{CFO}$, division $\mathrm{COO}$, division president, division vice president, head of division, regional CEO, regional $\mathrm{CFO}$, regional president, and regional vice president. Because industry expertise can be gained from working for either public or private companies in an industry, we gather industry information for both the public and private firms that an independent director has worked for. We use a number of data sources for this purpose. For the director's past employers that are publicly listed companies, we obtain their industry classification from Compustat and the Center for Research in Security Prices (CRSP). For the director's past employers that are privately held companies, we use Capital IQ, Orbis, Manta, and Google searches to identify their industry affiliations. ${ }^{6}$ We cross check each reference to ensure data consistency and accuracy whenever possible. The independent directors in our sample have 13,513 prior employers, for 13,341 of which we are able to identify industry information (10,065 at the 4-digit SIC level and 3,276 at the 2-digit SIC level). ${ }^{7}$ Of the firms with identifiable industry information, 2,643 are public firms. An independent director is coded as having industry expertise or alternatively classified as an IED if he or she has previously held a director or executive position at another firm in the same 2-digit SIC industry as the firm on whose board he or she sits. ${ }^{8}$

\footnotetext{
${ }^{5}$ BoardEx began covering board director information of S\&P 500, S\&P mid-cap 400, and S\&P small-cap 600 firms in 2000 and gradually increased its coverage of U.S. firms over time.

${ }^{6}$ The industry identification for private firms is very labor intensive because private firms significantly outnumber public firms, and we need to mostly rely on manual searches and matching to determine their industry classification. This is why we limit our sample to only S\&P 500 firms in order to keep our data-collection efforts manageable.

${ }^{7}$ We exclude from our analysis 172 prior employers for which we are unable to accurately identify industry information.

${ }^{8}$ Given the size and prominence of the S\&P 500 companies that populate our sample, few of their independent directors have missing profiles in BoardEx. For example, among the unique 2,421 audit committee independent directors in our sample, only 3 of them have no employment history reported in BoardEx. To be conservative, we code an independent director as having no industry expertise if
} 
We obtain firm financial information from Compustat, stock price and return data from CRSP, and board characteristics from BoardEx. As is customary in the literature, we exclude financial firms (1-digit SIC code: 6) and utility firms (2-digit SIC code: 49) because these firms are regulated. We require firms to have sufficient information for the construction of the dependent and independent variables in the variety of analyses of the paper. The sample size in each analysis varies depending on the firm policy we examine and model specification we use. For the earnings management analysis that we focus on, our baseline sample consists of 2,744 firm-year observations from 2000 to 2007 for 445 unique firms that were part of the S\&P 500 index during the time period. We lag all independent variables by 1 year to alleviate any reverse causality problem.

\section{B. Summary Statistics}

Table 1 presents the summary statistics of the key variables in the earnings management analysis. Detailed variable definitions are in the Appendix. All financial variables are winsorized at the 1 st and 99 th percentiles of their distributions to reduce the influence of outliers. The main measure of earnings management in our analysis is the absolute value of performance-adjusted abnormal accruals scaled by the lagged book value of total assets. It has a mean of 5\% and a median of $3.2 \%$ in our sample. We also construct both an ex ante and an ex post probability of financial misrepresentation as additional measures of earnings management. Following Dechow et al. (2011), we calculate an $F$-score for each firm, which represents the firm's ex ante probability of committing serious financial misstatements. The average (median) firm in our sample has an $F$-score of $1.022(0.981)$. For the ex post measure, we use a firm's earnings restatement as an indicator of whether the firm has committed financial misconduct. There are 231 firm years in our sample in which firms engaged in intentional earnings manipulation that resulted in irregularity restatements (Hennes et al. (2008)). We describe in detail the abnormal accruals estimation, the calculation of the $F$-score, and the identification of irregularity restatements in Internet Appendix A.

With respect to firm-level characteristics, the mean (median) firm in our sample has a book value of total assets of $\$ 19.211$ (\$7.443) billion, age of 35 (37.5) years, leverage ratio of $0.23(0.22)$, Tobin's $Q$ of $2.16(1.76)$, return on assets (ROA) of $7.2 \%(5.3 \%)$, and standard deviation of the ratio of sales to total assets of 0.122 (0.091). We also create three variables to measure firms' incentives to manipulate earnings. Following Bergstresser and Philippon (2006), we construct a variable, CEO_INCENTIVE, to measure a CEO's earnings management incentives driven by his or her equity-based compensation. It is equal to delta/(delta + cash compensation), where delta is the dollar change in the CEO's stock and stock option portfolio per $1 \%$ increase in stock price (Core and Guay (2002)) and cash compensation is the CEO's salary plus bonus. The average (median) CEO incentive ratio is equal to $0.324(0.247)$.

he or she has no employment history reported in BoardEx. Excluding directors with missing BoardEx profiles or excluding the firm-year observations affected by these directors does not change our results. 
TABLE 1

Summary Statistics

In Table 1, the sample consists of 2,744 firm-year observations from 2000 to 2007.

\begin{tabular}{|c|c|c|c|c|c|c|}
\hline Variable & $N$ & Mean & Median & Q1 & Q3 & $\begin{array}{l}\text { Standard } \\
\text { Deviation } \\
\end{array}$ \\
\hline Absolute value of abnormal accruals & 2,744 & 0.050 & 0.032 & 0.013 & 0.066 & 0.053 \\
\hline$F$-score & 2,744 & 1.022 & 0.981 & 0.672 & 1.315 & 0.440 \\
\hline Irregularity & 2,744 & 0.084 & 0.000 & 0.000 & 0.000 & 0.278 \\
\hline Total assets (billions of $\$$ ) & 2,744 & 19.211 & 7.443 & 3.208 & 17.493 & 49.628 \\
\hline FIRM_AGE & 2,744 & 35.020 & 37.500 & 18.000 & 52.000 & 17.362 \\
\hline LEVERAGE & 2,744 & 0.231 & 0.223 & 0.119 & 0.321 & 0.156 \\
\hline TOBIN_Q & 2,744 & 2.159 & 1.764 & 1.322 & 2.602 & 1.241 \\
\hline ROA & 2,744 & 0.072 & 0.053 & 0.011 & 0.117 & 0.125 \\
\hline STD_SALES/ASSETS & 2,744 & 0.122 & 0.091 & 0.056 & 0.155 & 0.101 \\
\hline CEO_INCENTIVE & 2,744 & 0.324 & 0.247 & 0.144 & 0.435 & 0.243 \\
\hline AUDITOR_INDUSTRY_MARKET_SHARE & 2,744 & 0.293 & 0.273 & 0.196 & 0.372 & 0.142 \\
\hline REPURCHASE_INCENTIVE & 2,744 & 0.172 & 0.000 & 0.000 & 0.000 & 0.378 \\
\hline SEO_INCENTIVE & 2,744 & 0.028 & 0.000 & 0.000 & 0.000 & 0.166 \\
\hline AC_IED_PERCENTAGE & 2,744 & 0.230 & 0.167 & 0.000 & 0.400 & 0.268 \\
\hline BOARD_SIZE & 2,744 & 10.795 & 11.000 & 9.000 & 12.000 & 2.462 \\
\hline BOARD_INDEPENDENCE & 2,744 & 0.726 & 0.750 & 0.632 & 0.857 & 0.164 \\
\hline CEO/CHAIRMAN & 2,744 & 0.697 & 1.000 & 0.000 & 1.000 & 0.460 \\
\hline BOARD_BUSYNESS & 2,744 & 0.171 & 0.143 & 0.000 & 0.273 & 0.172 \\
\hline AC_SIZE & 2,744 & 4.500 & 4.000 & 4.000 & 5.000 & 1.279 \\
\hline AC_INDEPENDENCE & 2,744 & 0.927 & 1.000 & 1.000 & 1.000 & 0.156 \\
\hline AC_BUSYNESS & 2,744 & 0.272 & 0.250 & 0.000 & 0.400 & 0.237 \\
\hline AC_FIN_EXPERT_PERCENTAGE & 2,744 & 0.249 & 0.250 & 0.000 & 0.400 & 0.214 \\
\hline
\end{tabular}

Previous studies document that companies tend to manage their earnings upward through positive accruals prior to SEOs and downward through negative accruals prior to open-market stock repurchases. Therefore, we construct two additional variables to capture firms' incentives to manage earnings before these two types of major corporate events. Specifically, REPURCHASE_INCENTIVE is an indicator variable that is equal to 1 if a firm makes an open-market stock repurchase in the next fiscal year, and 0 otherwise, and SEO_INCENTIVE is an indicator variable that is equal to 1 if a firm issues seasoned equity in the next fiscal year, and 0 otherwise. The average (median) REPURCHASE_ INCENTIVE is $0.172(0.000)$, and the average (median) SEO_INCENTIVE is $0.028(0.000)$.

The variable AUDITOR_INDUSTRY_MARKET_SHARE represents an auditor's market share in a particular industry. We use it to capture the degree of specialization of a firm's auditor in the firm's industry, to the extent that auditors experienced in the industry are better able to detect and prevent aggressive earnings management. We use the full Compustat database to compute each auditor's industry market share, which is equal to the aggregate sales of the auditor's clients in each 2-digit SIC industry divided by the total sales of all firms in the same 2-digit SIC industry. For the average (median) firm, its auditor's market share in its industry is $0.293(0.273)$.

As for board characteristics, our focus is on the presence of IEDs on a firm's board and audit committee. We construct two variables to measure the presence of IEDs on the board. The first variable, BOARD_IED_PERCENTAGE, is the percentage of IEDs among independent directors, and the second variable, BOARD_IED_MAJORITY, is a dummy variable that is equal to 1 if at least $50 \%$ of independent directors are IEDs. In the same fashion, we also construct 
two variables, AC_IED_PERCENTAGE and AC_IED_MAJORITY, to measure independent director industry expertise on a board's audit committee. The two binary specifications, BOARD_IED_MAJORITY and AC_IED_MAJORITY, are to capture the possibility that the effect of independent director industry expertise may manifest itself only when IEDs are in the majority of the independent director group on the board or audit committee. For the average (median) firm in our sample, $25.3 \%(20 \%)$ of the independent directors on the full board have prior experience from the firm's industry, and $23 \%$ (16.7\%) of the independent directors on the audit committee are IEDs. IEDs represent a majority of independent directors on the full board (audit committee) in 19.6\% (21\%) of our sample firms.

With respect to other board and audit committee characteristics, the mean (median) firm in our sample has 10.795 (11) board members, 72.6\% (75\%) of whom are independent. For the average (median) firm in our sample, $17.1 \%$ $(14.3 \%)$ of its independent directors are considered busy. ${ }^{9}$ In about $70 \%$ of the firm years, the CEO is also chairman of the board. The average (median) firm's audit committee has 4.5 (4) members, of whom $92.7 \%$ (100\%) are independent, likely as a result of SOX and the more stringent listing standards of NYSE and NASDAQ. About $27.2 \%$ (25\%) of the independent directors on the audit committee of the average (median) firm are busy. To capture the presence and influence of financial experts on audit committees, we create a variable, AC_FIN_EXPERT_ PERCENTAGE, which is the percentage of independent directors with financial expertise on a firm's audit committee. ${ }^{10}$ For the average (median) firm in our sample, $24.9 \%$ (25\%) of audit committee members have financial expertise. We report the correlations between the variables used in our analysis in Internet Appendix B.

\section{Analysis of Earnings Management}

\section{A. Baseline Analysis}

Our expert monitor hypothesis predicts that the presence of IEDs will improve the effectiveness of board oversight and reduce earnings management, whereas the compromised monitor hypothesis suggests a negative effect of IEDs on board monitoring and the quality of financial reporting. To test these conjectures, we follow Dechow, Sloan, and Sweeney (1995) in using the modified Jones (1991) model to estimate abnormal accruals. We also follow Kothari et al. (2005) and Gong et al. (2008) to adjust our abnormal accruals for firm performance. Firms can manipulate their reported earnings through either positive or negative abnormal accruals. Positive abnormal accruals increase reported earnings

\footnotetext{
${ }^{9} \mathrm{~A}$ director is considered "busy" if he or she holds three or more directorships at publicly traded firms.

${ }^{10} \mathrm{~A}$ director is considered as having financial expertise if he or she has an undergraduate or graduate degree in accounting, is a certified public accountant (CPA), or has held executive positions such as $\mathrm{CFO}$, treasurer, controller, or comptroller. Previous studies find that the presence of financial experts on the board or audit committee can reduce firms' earnings management behavior and probability of financial misreporting (Klein (2002), Agrawal and Chadha (2005), and Dhaliwal et al. (2010)).
} 
and boost perceived firm performance and stock price, allowing managers to receive undeserved bonus and pay raises and to sell shares or exercise stock options at inflated prices. Negative abnormal accruals decrease reported earnings and potentially depress stock price. But they can provide cushion or "reserve" that managers can tap into later when future performance falls short of expectations. This enables managers to smooth earnings and present a false picture of firm performance to outside shareholders. Because we are concerned with the extent of earnings management rather than the direction of earnings management, we follow Klein (2002), Bergstresser and Philippon (2006), Cohen, Dey, and Lys (2008), and Hazarika et al. (2012) in using the absolute value of our performanceadjusted abnormal accruals (ABSAA) as the measure of earnings management and the main dependent variable in regressions.

Given the direct supervision by audit committees of corporate financial reporting, we focus on IED presence on the audit committee in our analyses. We estimate regressions of the absolute value of abnormal accruals (ABSAA) against measures of audit committee IED presence while controlling for other firm financial and governance characteristics. A major empirical challenge that concerns most, if not all, studies in the corporate governance literature is the endogeneity or omitted-variable problem. In our context, the problem arises when IEDs are not randomly assigned to firms and their presence in a firm may be determined by factors related to the firm's demand for IEDs or the willingness of director candidates with industry experience to join the firm. If some of these factors are correlated with the firm's earnings management, but are not adequately controlled for in our regressions, then measures of IED presence could be correlated with the error terms of the abnormal accruals regressions, thereby biasing the coefficient estimates. As a first attempt to deal with this concern, we follow Fich and Shivdasani (2006) and control for firm fixed effects (FFE) in the abnormal accruals regressions. This approach will be effective in mitigating the endogeneity issue to the extent that some unobservable time-invariant firm characteristics are related to both earnings management and IED presence.

Column 1 of Table 2 presents the coefficient estimates from the FFE regressions with robust $t$-statistics based on standard errors adjusted for heteroskedasticity and firm-level clustering. The key independent variable is AC_IED_ PERCENTAGE, which we find is significantly and negatively associated with ABSAA. In untabulated results, we find that AC_IED_MAJORITY is also significantly and negatively related to ABSAA. These results lend support to our expert monitor hypothesis and suggest that independent directors with relevant industry experience indeed are more effective in ensuring the integrity of a firm's financial disclosure and reducing the earnings management behavior by managers. These FFE regression results also provide at least some assurance against the endogeneity concern. ${ }^{11}$

\footnotetext{
${ }^{11}$ We also estimate the abnormal accruals regressions against the two measures of IED presence at the full board level, BOARD_IED_PERCENTAGE and BOARD_IED_MAJORITY. In untabulated results, we find that the board-level IED presence measures are negatively related with the absolute value of abnormal accruals, but the relation is not statistically significant at the conventional level. The lack of statistical significance is likely due to the fact that not all independent directors on the
} 
TABLE 2

Baseline Regressions of Earnings Management

\begin{tabular}{|c|c|c|c|}
\hline Variables & ABSAA & F-Score & Irregularity \\
\hline AC_IED_PERCENTAGE & $\begin{array}{l}-0.032^{\star \star \star} \\
(-2.596)\end{array}$ & $\begin{array}{l}-0.171^{\star *} \\
(-2.573)\end{array}$ & $\begin{array}{l}-0.247^{\star} \\
(-1.673)\end{array}$ \\
\hline FIRM_SIZE & $\begin{array}{l}0.017^{\star \star \star} \\
(2.695)\end{array}$ & $\begin{array}{l}0.427^{\text {***}} \\
(11.634)\end{array}$ & $\begin{array}{c}0.011 \\
(0.136)\end{array}$ \\
\hline FIRM_AGE & $\begin{array}{l}-0.013 \\
(-0.374)\end{array}$ & $\begin{array}{l}-0.356 \\
(-0.967)\end{array}$ & $\begin{array}{l}-0.004 \\
(-1.027)\end{array}$ \\
\hline LEVERAGE & $\begin{array}{l}-0.018 \\
(-1.021)\end{array}$ & $\begin{array}{c}0.159 \\
(1.374)\end{array}$ & $\begin{array}{c}0.018 \\
(0.042)\end{array}$ \\
\hline TOBIN_Q & $\begin{array}{l}0.005^{\star \star} \\
(2.023)\end{array}$ & $\begin{array}{c}0.017 \\
(1.223)\end{array}$ & $\begin{array}{l}-0.051 \\
(-0.884)\end{array}$ \\
\hline $\mathrm{ROA}$ & $\begin{array}{l}-0.117^{\star \star \star} \\
(-4.399)\end{array}$ & $\begin{array}{l}-0.211 \\
(-1.523)\end{array}$ & $\begin{array}{l}-0.951^{* *} \\
(-2.035)\end{array}$ \\
\hline STD_SALES/ASSETS & $\begin{array}{l}0.060^{\star \star \star} \\
(2.963)\end{array}$ & $\begin{array}{r}0.234^{\star} \\
(1.884)\end{array}$ & $\begin{array}{c}0.382 \\
(0.769)\end{array}$ \\
\hline BOARD_SIZE & $\begin{array}{l}-0.002 \\
(-1.401)\end{array}$ & $\begin{array}{l}-0.011^{\star} \\
(-1.939)\end{array}$ & $\begin{array}{l}-0.005 \\
(-0.150)\end{array}$ \\
\hline BOARD_INDEPENDENCE & $\begin{array}{c}0.004 \\
(0.203)\end{array}$ & $\begin{array}{l}-0.042 \\
(-0.359)\end{array}$ & $\begin{array}{l}-0.975^{\star} \\
(-1.933)\end{array}$ \\
\hline CEO/CHAIRMAN & $\begin{array}{c}0.005 \\
(1.508)\end{array}$ & $\begin{array}{l}-0.014 \\
(-0.633)\end{array}$ & $\begin{array}{l}-0.001 \\
(-0.009)\end{array}$ \\
\hline BOARD_BUSYNESS & $\begin{array}{l}-0.002 \\
(-0.171)\end{array}$ & $\begin{array}{l}-0.041 \\
(-0.795)\end{array}$ & $\begin{array}{c}0.157 \\
(0.470)\end{array}$ \\
\hline AC_SIZE & $\begin{array}{c}0.000 \\
(0.223)\end{array}$ & $\begin{array}{l}-0.003 \\
(-0.324)\end{array}$ & $\begin{array}{l}-0.049 \\
(-0.106)\end{array}$ \\
\hline AC_INDEPENDENCE & $\begin{array}{c}0.014 \\
(1.110)\end{array}$ & $\begin{array}{l}-0.069 \\
(-0.907)\end{array}$ & $\begin{array}{l}-0.098^{\star \star} \\
(-2.017)\end{array}$ \\
\hline AC_BUSYNESS & $\begin{array}{l}-0.010 \\
(-1.333)\end{array}$ & $\begin{array}{l}0.007 \\
(0.158)\end{array}$ & $\begin{array}{l}-0.038 \\
(-0.157)\end{array}$ \\
\hline AC_FIN_EXPERT_PERCENTAGE & $\begin{array}{l}-0.002 \\
(-0.231)\end{array}$ & $\begin{array}{c}0.002 \\
(0.029)\end{array}$ & $\begin{array}{c}0.025 \\
(0.080)\end{array}$ \\
\hline AUDITOR_INDUSTRY_MARKET_SHARE & $\begin{array}{c}-0.042 \\
(-1.618)\end{array}$ & $\begin{array}{l}-0.008 \\
(-0.063)\end{array}$ & $\begin{array}{c}0.424 \\
(0.791)\end{array}$ \\
\hline CEO_INCENTIVE & $\begin{array}{l}-0.009 \\
(-0.933)\end{array}$ & $\begin{array}{c}0.054 \\
(1.257)\end{array}$ & $\begin{array}{l}0.027 \\
(0.099)\end{array}$ \\
\hline REPURCHASE_INCENTIVE & $\begin{array}{l}-0.009 \\
(-1.274)\end{array}$ & $\begin{array}{l}-0.028 \\
(-0.740)\end{array}$ & $\begin{array}{l}-0.058 \\
(-0.664)\end{array}$ \\
\hline SEO_INCENTIVE & $\begin{array}{c}0.000 \\
(0.040)\end{array}$ & $\begin{array}{c}0.016 \\
(1.249)\end{array}$ & $\begin{array}{c}0.065 \\
(0.277)\end{array}$ \\
\hline Constant & $\begin{array}{c}0.416 \\
(0.305)\end{array}$ & $\begin{array}{l}10.983 \\
(0.772)\end{array}$ & $\begin{array}{r}1.564^{*} \\
(1.766)\end{array}$ \\
\hline $\begin{array}{l}\text { Firm fixed effects } \\
\text { Industry fixed effects } \\
\text { Year fixed effects }\end{array}$ & $\begin{array}{l}\text { Yes } \\
\text { No } \\
\text { Yes }\end{array}$ & $\begin{array}{l}\text { Yes } \\
\text { No } \\
\text { Yes }\end{array}$ & $\begin{array}{l}\text { No } \\
\text { Yes } \\
\text { Yes }\end{array}$ \\
\hline $\begin{array}{l}\text { Firm-year observations } \\
\text { Pseudo- } R^{2}\end{array}$ & $\begin{array}{l}2,744 \\
0.418\end{array}$ & $\begin{array}{l}2,744 \\
0.762\end{array}$ & $\begin{array}{l}2,744 \\
0.194\end{array}$ \\
\hline
\end{tabular}

To the extent that aggressive earnings management through accruals can lead to financial misreporting, we next examine whether the presence of independent

board are directly involved with a firm's financial reporting process, and highlights the importance of focusing on audit committees. 
director industry expertise on the audit committee can reduce a firm's likelihood of committing financial misconduct. We consider both an ex ante and an ex post measure for financial misconduct. Following Dechow et al. (2011), we calculate an $F$-score for each firm, which represents the firm's ex ante probability of committing serious financial misstatements. Dechow et al. compile a database of firms that have been subject to enforcement actions by the U.S. Securities and Exchange Commission (SEC) for allegedly misstating their financial statements. They analyze the financial characteristics of misstating firms and develop a model to predict misstatements. The output of this analysis is then used to create a scaled probability ( $F$-score) that can reflect the likelihood of earnings management or misstatement.

We estimate FFE regressions of the $F$-score against the presence of IEDs on the audit committee and present the results in column 2 of Table 2. We find that the percentage of IEDs on the audit committee is significantly and negatively related to a firm's $F$-score, suggesting that IEDs on the audit committee enhance board monitoring of the firm's financial reporting process and reduce its ex ante probability of earnings manipulation.

For the ex post measure, we use a firm's earnings restatement as an indicator of whether the firm has committed financial misrepresentation. The advantage of this measure is that it is likely to capture the most egregious earnings manipulations and is less subject to the measurement error problems plaguing other measures of earnings manipulation (Dechow, Ge, and Schrand (2010)). But a caveat of using this measure is that we may miss earnings management practices that do not result in restatements. Among the 2,744 firm-years in our sample, there are 231 firm-years in which companies engaged in intentional earnings manipulation that resulted in irregularity restatements later. We perform a probit analysis of the likelihood of a firm committing intentional financial misreporting and present the coefficient estimates in column 3 of Table 2. The dependent variable is equal to 1 for fiscal years during which firms intentionally manipulate earnings, and 0 otherwise. We find that the probability of intentional financial misreporting that leads to future restatement is significantly negatively related to IED presence on the audit committee.

We also note that our findings are not only statistically significant but also economically meaningful. Specifically, we find that, all else being equal, increasing the percentage of IEDs on a firm's audit committee from the 1st quartile to the 3rd quartile reduces ABSAA by about 0.013 and the $F$-score by 0.068 , which represents an approximately $25.6 \%$ reduction of the sample mean of 0.05 for ABSAA and a $6.7 \%$ reduction of the sample mean of 1.022 for the $F$-score. In addition, increasing the percentage of IEDs on the audit committee from the 1st quartile to the 3rd quartile reduces the likelihood of earnings manipulation by $1.6 \%$, approximately $19 \%$ of the unconditional probability of $8.4 \%$ in our sample.

Overall, the evidence in Section III provides strong support for the expert monitor hypothesis that independent director industry expertise improves the effectiveness of the audit committee's oversight of corporate financial reporting and limits managerial attempts to distort reported financial results. Our results are robust to the use of multiple proxies to capture managers' earnings manipulation 
activities, including abnormal accruals, $F$-score, and irregularity-driven earnings restatements.

In further analysis, we also examine whether IED presence on the audit committee is related to other measures of earnings management, for example, beating or meeting analyst forecasts (Cheng and Warfield (2005)) and income smoothing (Burgstahler, Hail, and Leuz (2006)). In untabulated results, we find that IED presence on the audit committee reduces both the likelihood of beating or meeting analyst forecasts and the magnitude of income smoothing, but the effect is not statistically significant. The lack of significance for the results from these two analyses is likely due to the possibility that firms may choose to manipulate analyst expectations rather than earnings in order to beat or meet analyst forecasts, and the ambiguity about whether smoother earnings relative to cash flows reflect certain characteristics of a firm's earnings-generating process or intentional managerial manipulation (Dechow et al. (2010)).

We also investigate whether IED presence on the audit committee affects real earnings management, because Cohen et al. (2008) find that after the passage of SOX, firms are more likely to engage in real earnings management as a substitute for accrual earnings management due to regulatory pressure and capital market scrutiny. We do not find any significant connection between audit committee IED presence and earnings management through real activities. One possible reason for this is that audit committees are less concerned about real earnings management because it does not risk violating GAAP and thus does not have the same potential for causing financial and reputational damage to firms and directors as aggressive accruals management and financial misreporting do.

\section{B. Cross-Sectional Variations in the Effect of IEDs on Earnings Management}

In this section, we explore whether the effect of independent director industry expertise on earnings management varies across industry, firm, and CEO characteristics. More specifically, we examine whether the presence of IEDs has a more pronounced effect on limiting managerial attempts to manipulate earnings at i) firms associated with greater information asymmetry, which creates more potential for managerial opportunism while hindering board monitoring efforts (Adams and Ferreira (2007), Harris and Raviv (2008), and Duchin, Matsusaka, and Ozbas (2010)); ii) firms operating in more homogeneous industries, where knowledge and experience gained at one firm are more transferable and applicable to another (Parrino (1997)); iii) firms where equity-based compensation gives rise to more incentives for managers to manipulate earnings (Bergstresser and Philippon (2006)); and iv) firms whose earnings management activity is at greater risk of violating GAAP.

To test the first conjecture, we measure a firm's information asymmetry by its idiosyncratic volatility, computed as the standard deviation of its daily excess stock returns over the past year estimated using the Fama-French (1992) 3-factor model. We then partition our sample into two subsamples based on whether a firm's idiosyncratic volatility is above or below the sample median, and estimate the abnormal accruals regressions separately in the two subsamples. Columns 1 


\section{TABLE 3}

\section{Cross-Sectional Variations in the Effect of IEDs on Earnings Management: Industry, Firm, and CEO Characteristics}

In Table 3, the sample consists of 2,744 firm-year observations from 2000 to 2007 . The dependent variable is the absolute value of abnormal accruals in Panel A, F-score in Panel B, and irregularity earnings restatement in Panel C. We partition the sample into subsamples based on a firm's idiosyncratic risk, industry homogeneity, CEO incentive ratio, and magnitude of abnormal accruals. In parentheses are $t$-statistics based on standard errors adjusted for heteroskedasticity (White (1980)) and firm clustering (Petersen (2009)). ${ }^{* \star},{ }^{* *}$, and * indicate statistical significance based on two-sided tests at the $1 \%$, $5 \%$, and $10 \%$ levels, respectively.

\begin{tabular}{|c|c|c|c|c|c|c|c|c|}
\hline & 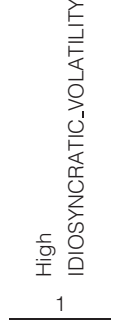 & 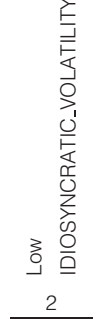 & 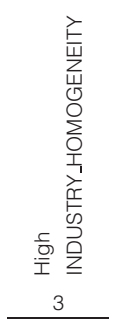 & 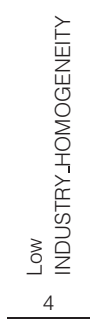 & 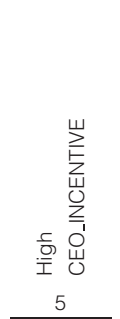 & 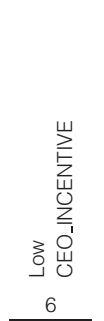 & 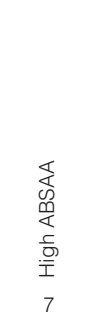 & $\begin{array}{l}\frac{1}{4} \\
\text { D } \\
\frac{1}{4} \\
3 \\
0 \\
8 \\
8\end{array}$ \\
\hline \multicolumn{9}{|l|}{ Panel A. ABSAA } \\
\hline $\begin{array}{l}\text { AC_IED_- } \\
\text { PERCENTAGE }\end{array}$ & $\begin{array}{l}-0.051^{\star \star} \\
(-2.376)\end{array}$ & $\begin{array}{l}-0.019 \\
(-1.112)\end{array}$ & $\begin{array}{l}-0.046^{\star *} \\
(-2.399)\end{array}$ & $\begin{array}{l}-0.020 \\
(-1.146)\end{array}$ & $\begin{array}{l}-0.036^{\star *} \\
(-2.182)\end{array}$ & $\begin{array}{l}-0.035 \\
(-1.600)\end{array}$ & $\begin{array}{r}-0.042^{*} \\
(-1.911)\end{array}$ & $\begin{array}{l}-0.001 \\
(-0.202)\end{array}$ \\
\hline $\begin{array}{l}\text { Control variables } \\
\text { Firm fixed effects } \\
\text { Year fixed effects }\end{array}$ & $\begin{array}{l}\text { Yes } \\
\text { Yes } \\
\text { Yes }\end{array}$ & $\begin{array}{l}\text { Yes } \\
\text { Yes } \\
\text { Yes }\end{array}$ & $\begin{array}{l}\text { Yes } \\
\text { Yes } \\
\text { Yes }\end{array}$ & $\begin{array}{l}\text { Yes } \\
\text { Yes } \\
\text { Yes }\end{array}$ & $\begin{array}{l}\text { Yes } \\
\text { Yes } \\
\text { Yes }\end{array}$ & $\begin{array}{l}\text { Yes } \\
\text { Yes } \\
\text { Yes }\end{array}$ & $\begin{array}{l}\text { Yes } \\
\text { Yes } \\
\text { Yes }\end{array}$ & $\begin{array}{l}\text { Yes } \\
\text { Yes } \\
\text { Yes }\end{array}$ \\
\hline $\begin{array}{l}\text { Firm-year observations } \\
R^{2}\end{array}$ & $\begin{array}{l}1,355 \\
0.475\end{array}$ & $\begin{array}{l}1,385 \\
0.482\end{array}$ & $\begin{array}{l}1,267 \\
0.424\end{array}$ & $\begin{array}{l}1,344 \\
0.422\end{array}$ & $\begin{array}{l}1,370 \\
0.508\end{array}$ & $\begin{array}{l}1,374 \\
0.492\end{array}$ & $\begin{array}{l}1,371 \\
0.515\end{array}$ & $\begin{array}{l}1,373 \\
0.359\end{array}$ \\
\hline \multicolumn{9}{|l|}{ Panel B. F-Score } \\
\hline $\begin{array}{l}\text { AC_IED_ } \\
\text { PERCENTAGE }\end{array}$ & $\begin{array}{l}-0.229^{* \star \star} \\
(-2.831)\end{array}$ & $\begin{array}{l}-0.107 \\
(-0.983)\end{array}$ & $\begin{array}{l}-0.298^{\star \star \star} \\
(-3.270)\end{array}$ & $\begin{array}{l}-0.075 \\
(-0.778)\end{array}$ & $\begin{array}{l}-0.236^{\star *} \\
(-2.505)\end{array}$ & $\begin{array}{l}-0.104 \\
(-0.881)\end{array}$ & $\begin{array}{l}-0.207^{\star} \\
(-1.887)\end{array}$ & $\begin{array}{l}-0.113 \\
(-1.040)\end{array}$ \\
\hline $\begin{array}{l}\text { Control variables } \\
\text { Firm fixed effects } \\
\text { Year fixed effects }\end{array}$ & $\begin{array}{l}\text { Yes } \\
\text { Yes } \\
\text { Yes }\end{array}$ & $\begin{array}{l}\text { Yes } \\
\text { Yes } \\
\text { Yes }\end{array}$ & $\begin{array}{l}\text { Yes } \\
\text { Yes } \\
\text { Yes }\end{array}$ & $\begin{array}{l}\text { Yes } \\
\text { Yes } \\
\text { Yes }\end{array}$ & $\begin{array}{l}\text { Yes } \\
\text { Yes } \\
\text { Yes }\end{array}$ & $\begin{array}{l}\text { Yes } \\
\text { Yes } \\
\text { Yes }\end{array}$ & $\begin{array}{l}\text { Yes } \\
\text { Yes } \\
\text { Yes }\end{array}$ & $\begin{array}{l}\text { Yes } \\
\text { Yes } \\
\text { Yes }\end{array}$ \\
\hline $\begin{array}{l}\text { Firm-year observations } \\
R^{2}\end{array}$ & $\begin{array}{l}1,355 \\
0.747\end{array}$ & $\begin{array}{l}1,385 \\
0.837\end{array}$ & $\begin{array}{l}1,267 \\
0.752\end{array}$ & $\begin{array}{l}1,344 \\
0.735\end{array}$ & $\begin{array}{l}1,370 \\
0.812\end{array}$ & $\begin{array}{l}1,374 \\
0.792\end{array}$ & $\begin{array}{l}1,371 \\
0.749\end{array}$ & $\begin{array}{l}1,373 \\
0.855\end{array}$ \\
\hline \multicolumn{9}{|l|}{ Panel C. Irregularity } \\
\hline $\begin{array}{l}\text { AC_IED_- } \\
\text { PERCENTAGE }\end{array}$ & $\begin{array}{l}-0.562^{\star} \\
(-1.708)\end{array}$ & $\begin{array}{l}-0.209 \\
(-0.946)\end{array}$ & $\begin{array}{r}-0.614^{*} \\
(-1.767)\end{array}$ & $\begin{array}{l}-0.454 \\
(-1.234)\end{array}$ & 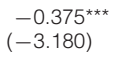 & $\begin{array}{l}-0.126 \\
(-0.515)\end{array}$ & $\begin{array}{l}-0.252 \\
(-1.415)\end{array}$ & $\begin{array}{l}-0.212 \\
(-0.976)\end{array}$ \\
\hline $\begin{array}{l}\text { Control variables } \\
\text { Industry fixed effects } \\
\text { Year fixed effects }\end{array}$ & $\begin{array}{l}\text { Yes } \\
\text { Yes } \\
\text { Yes }\end{array}$ & $\begin{array}{l}\text { Yes } \\
\text { Yes } \\
\text { Yes }\end{array}$ & $\begin{array}{l}\text { Yes } \\
\text { Yes } \\
\text { Yes }\end{array}$ & $\begin{array}{l}\text { Yes } \\
\text { Yes } \\
\text { Yes }\end{array}$ & $\begin{array}{l}\text { Yes } \\
\text { Yes } \\
\text { Yes }\end{array}$ & $\begin{array}{l}\text { Yes } \\
\text { Yes } \\
\text { Yes }\end{array}$ & $\begin{array}{l}\text { Yes } \\
\text { Yes } \\
\text { Yes }\end{array}$ & $\begin{array}{l}\text { Yes } \\
\text { Yes } \\
\text { Yes }\end{array}$ \\
\hline $\begin{array}{l}\text { Firm-year observations } \\
\text { Pseudo- } R^{2}\end{array}$ & $\begin{array}{l}1,355 \\
0.209\end{array}$ & $\begin{array}{l}1,385 \\
0.252\end{array}$ & $\begin{array}{l}1,267 \\
0.237\end{array}$ & $\begin{array}{l}1,344 \\
0.205\end{array}$ & $\begin{array}{l}1,370 \\
0.286\end{array}$ & $\begin{array}{l}1,374 \\
0.217\end{array}$ & $\begin{array}{l}1,371 \\
0.208\end{array}$ & $\begin{array}{l}1,373 \\
0.231\end{array}$ \\
\hline
\end{tabular}

and 2 in Panel A of Table 3 present the coefficient estimates, where column 1 is for the subsample with above-sample-median information asymmetry and column 2 is for the subsample with below-sample-median information asymmetry. For brevity, for all of the regressions in this section as well as the next one, we report only the coefficient on the key independent variable, AC_IED_ PERCENTAGE, while suppressing the coefficient estimates on all control variables.

We find that the presence of IEDs on the audit committee significantly reduces earnings management only in the subsample of firms with higher information asymmetry, as evidenced by the significant and negative coefficient on AC_IED_PERCENTAGE in column 1. This evidence is consistent with our 
hypothesis and indicates that the value of independent director industry experience in reducing earnings management manifests itself precisely in situations where managers, ex ante, are more likely to engage in such behavior and board monitoring would be difficult without industry expertise. ${ }^{12}$

We then examine how industry homogeneity affects the effectiveness of industry expertise in helping independent directors better constrain managerial distortion of reported earnings. We follow Parrino (1997) and measure industry homogeneity by the partial correlation of stock returns of firms in the same 2-digit SIC industry. The intuition is that if firms in the same industry employ similar production technologies, compete in similar product markets, and are subject to the influence of roughly the same set of economic forces, the correlations of their stock returns are likely to be higher. Specifically, for every month between Jan. 2000 and Dec. 2007, we create an equal-weighted industry index for each 2-digit SIC industry. Following Parrino (1997), industries with fewer than 35 firms are excluded from the analysis, and if an industry has more than 50 firms, a random sample of 50 firms is selected. We then regress a firm's monthly stock returns on the equal-weighted monthly industry index returns and the equal-weighted CRSP monthly returns. The partial correlation coefficient on the industry index returns is our measure of industry homogeneity. A higher partial correlation coefficient indicates a higher performance correlation among firms in an industry and thus higher industry homogeneity.

We partition our sample firms into two subsamples based on whether the homogeneity measure of a firm's industry is above or below the sample median. We then estimate the abnormal accruals regressions separately on the two subsamples and present the results in columns 3 and 4 in Panel A of Table 3, where column 3 is for the subsample of firms from more homogeneous industries and column 4 is for the subsample of firms from less homogeneous industries. We find that IED presence on the audit committee has a significantly negative effect on ABSAA only in the subsample of firms from more homogeneous industries. This is consistent with our hypothesis that industry expertise is more transferable between firms in homogeneous industries, in that independent directors can utilize the knowledge and experience they gained at one firm to better understand, analyze, and evaluate another firm's financial reporting.

In our next test, we investigate whether independent director industry expertise plays a more important role in reducing earnings management when CEOs, ex ante, are more likely to engage in earnings manipulations. Specifically, we partition our sample firms into two subsamples based on whether the CEO incentive ratio is above or below the sample median, because the CEO incentive ratio has been shown in the prior literature to increase firms' tendency to manage earnings (Bergstresser and Philippon (2006)). We then estimate the abnormal accruals regressions separately on the two subsamples and present the results in columns 5 and 6 in Panel A of Table 3, where column 5 is for the subsample of firms with higher CEO incentive ratios, and column 6 is for the subsample of firms with lower CEO incentive ratios. We find that IED presence on the audit committee

\footnotetext{
${ }^{12}$ We obtain similar results when using analyst forecast dispersion as an alternative proxy for information asymmetry.
} 
has a significantly negative effect on ABSAA only in the subsample of firms with higher CEO incentive ratios. This is consistent with our hypothesis that independent director industry expertise is more valuable when there are potentially higher incentives for CEOs to manage earnings.

Finally, we recognize that earnings management can be either within GAAP or in violation of GAAP. As explained in the Introduction, the reputation and labor market considerations will make independent directors averse to both within-GAAP and GAAP-violating earnings management, because often there is only a fine line separating the two types of earnings management activities, and it is difficult for independent directors sitting on the audit committees to determine whether firms have crossed it or not. In addition, even within-GAAP earnings management activities, if carried out too aggressively, may increase the risk of GAAP violation and trigger the reputational and labor market penalties for independent directors. Nevertheless, we expect independent directors to be more concerned about earnings management activities that are more likely to violate GAAP. Therefore, we expect the effect of audit committee industry expertise on earnings management to be more pronounced among firms in which the risk of violating GAAP is higher. We proxy for a firm's risk of violating GAAP by the magnitude of its abnormal accruals, because Dichev et al. (2013) suggest that large unexplained accruals can serve as a warning sign for financial misrepresentation. We partition our sample firms into two subsamples based on whether a firm's absolute value of performance-adjusted abnormal accruals is above or below the sample median. We then estimate the abnormal accruals regressions separately in the two subsamples and present the results in columns 7 and 8 in Panel A of Table 3. We find that audit committee industry expertise reduces earnings management in both subsamples, but the effect is statistically significant only in the subsample with higher abnormal accruals, consistent with our conjecture that audit committees have stronger incentives to limit more aggressive earnings management and prevent financial misconduct.

We repeat the previously described subsample regression analysis using the $F$-score and incidence of irregularity restatements as the ex ante and ex post measures of aggressive earnings management and financial misreporting, respectively. The results presented in Panel B (for $F$-score) and Panel C (for restatements) of Table 3 are largely consistent with those in Panel A that are based on abnormal accruals. They indicate that the presence of IEDs on the audit committee reduces firms' ex ante and ex post probabilities of committing intentional financial misreporting, but the effect is significant only in the subsamples of firms with higher information asymmetry, firms from more homogeneous industries, firms whose CEOs have more ex ante equity incentives to manipulate earnings, and firms at a higher risk of violating GAAP. The lone exception to this pattern is from columns 7 and 8 in Panel C, where we estimate regressions of the probability of irregularity restatement on subsamples created based on a firm's abnormal accruals.

\section{Decomposing Independent Director Industry Expertise}

In this section we delve into the fabric of the industry experience of independent directors and investigate whether some experiences are more relevant and 
important than others and thus are more valuable in enhancing independent directors' ability to curb firms' earnings management. We first consider the recentness of director experience. Independent directors can apply their previously acquired industry knowledge to analyze a firm's policy and decision making only when their prior experience is applicable to the firm's current situation. Because an industry's environment and characteristics may change over time, sometimes quite rapidly, due to technological obsolescence and advancement, firms entering and exiting from the industry, and regulations or deregulations, we hypothesize that industry experiences obtained more recently are more applicable to present situations and thus more effective in helping independent directors evaluate firms' financial reporting practice and limit earnings manipulation.

To test this conjecture, we reestimate the abnormal accruals regressions while replacing the variable AC_IED_PERCENTAGE with two new explanatory variables: the percentage of audit committee independent directors with industry experience obtained within the past 10 years and the percentage of audit committee independent directors with industry expertise obtained more than 10 years ago. Results presented in column 1 of Panel A in Table 4 indicate that the presence of IEDs on the audit committee is able to significantly reduce earnings management only when the industry experience is acquired recently, and, in this case, within the past 10 years.

We next examine whether the source of industry expertise matters. We first distinguish between industry experience obtained at public and private firms. Public firms are different from private firms in a number of dimensions, such as scale and complexity of operations, ownership and governance structures, access and exposure to capital markets, and compliance with rules and regulations imposed by stock exchanges and regulatory agencies. As a result, the financial reporting process itself and the myriad of considerations that factor into the process are likely to be drastically different between public and private firms. Given the context of our investigation, we hypothesize that industry experience obtained from working for a public company will be more pertinent in helping independent directors understand, analyze, and evaluate a firm's financial reporting practice and curb managerial attempts to manipulate earnings. To test this hypothesis, we replace the variable AC_IED_PERCENTAGE with two new explanatory variables: the proportion of audit committee independent directors who have industry experience obtained from public firms and the proportion of audit committee independent directors who have industry experience obtained solely from private firms. We reestimate the abnormal accruals regression and present the results in column 2 of Panel A in Table 4. Consistent with our argument, only the presence of independent director industry expertise acquired through public firms significantly reduces earnings management.

We then distinguish between industry experience obtained from serving as firm executives and that from serving as outside directors. We expect executive positions to provide greater access to information and more of an insider view of the operations and decision making at firms. Although outside directors can independently uncover information about the firms they serve, they still rely to a large extent on managers to provide them with necessary information. However, managers do not always have incentives to provide such information in a timely 
and truthful manner (Adams and Ferreira (2007), Harris and Raviv (2008)). As a result, the industry knowledge and expertise gained through executive positions are likely to be more accurate, up to date, and detailed than those gained by serving as outside directors. Therefore, we expect the former type of industry experience to be more effective in enabling independent directors to detect and control firms' earnings management. We examine this conjecture by creating two explanatory variables: the proportion of audit committee independent directors with industry experience acquired as corporate executives and the proportion of audit committee independent directors with industry experience acquired as outside directors only. We regress the absolute value of abnormal accruals against these two variables, along with the control variables, and report the results in column 3 of Panel A in Table 4. Consistent with our expectation, we find that only the presence of industry expertise of audit committee independent directors gained as corporate executives is significantly and negatively associated with earnings management.

Last, we examine whether director industry expertise gained through accounting-related positions is more effective in curtailing earnings management, as previous studies find that financial experts on audit committees can reduce firms' earnings management behavior (e.g., Klein (2002)). We replace the variable AC_IED_PERCENTAGE with two new explanatory variables: the proportion

\section{TABLE 4}

Cross-Sectional Variations in the Effect of IEDs on Earnings Management: Nature of Industry Expertise

In Table 4, the sample consists of 2,744 firm-year observations from 2000 to 2007 . The dependent variable is the absolute value of abnormal accruals in Panel A, F-score in Panel B, and irregularity earnings restatement in Panel C. We decompose director expertise by its recentness, whether it is from public or private firm work experience, whether it is acquired at the executive level, and whether it is acquired through finance- or accounting-related functional roles. In parentheses are $t$-statistics based on standard errors adjusted for heteroskedasticity (White (1980)) and firm clustering (Petersen (2009)). ${ }^{* * *},{ }^{* *}$, and ${ }^{*}$ indicate statistical significance based on two-sided tests at the $1 \%, 5 \%$, and $10 \%$ levels, respectively.

Panel A. ABSAA

AC_IED_PERCENTAGE (with recent 10-year experience) $\quad-0.024^{\star \star \star}$

$(-2.689)$

AC_IED_PERCENTAGE (without recent 10-year experience) $\quad-0.005$

AC_IED_PERCENTAGE (with public firm experience)

AC_IED_PERCENTAGE (without public firm experience)

AC_IED_PERCENTAGE (with executive experience)

AC_IED_PERCENTAGE (without executive experience)

AC_IED_PERCENTAGE (with financial expertise)

AC_IED_PERCENTAGE (without financial expertise)

Control variables

Firm fixed effects

Year fixed effects

Firm-year observations

$R^{2}$
$(-0.224)$

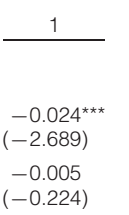

$-0.036^{\star \star}$
$(-2.273)$
-0.028
$(-1.354)$

$-0.036^{\star \star}$
$(-2.483)$
-0.024
$(-0.836)$

$-0.039^{* *}$

$(-2.053)$

$-0.019^{* *}$

$(-2.093)$

Yes

Yes

2,744

0.418 
TABLE 4 (continued)

Cross-Sectional Variations in the Effect of IEDs on Earnings Management: Nature of Industry Expertise

\begin{tabular}{|c|c|c|c|c|}
\hline & 1 & 2 & 3 & 4 \\
\hline \multicolumn{5}{|l|}{ Panel B. F-Score } \\
\hline AC_IED_PERCENTAGE (with recent 10-year experience) & $\begin{array}{l}-0.281^{\star *} \\
(-2.339)\end{array}$ & & & \\
\hline AC_IED_PERCENTAGE (without recent 10-year experience) & $\begin{array}{l}-0.158^{\star \star} \\
(-2.275)\end{array}$ & & & \\
\hline AC_IED_PERCENTAGE (with public firm experience) & & $\begin{array}{l}-0.270^{\star \star} \\
(-2.222)\end{array}$ & & \\
\hline AC_IED_PERCENTAGE (without public firm experience) & & $\begin{array}{l}-0.136^{\star} \\
(-1.875)\end{array}$ & & \\
\hline AC_IED_PERCENTAGE (with executive experience) & & & $\begin{array}{l}-0.182^{\star \star} \\
(-2.308)\end{array}$ & \\
\hline AC_IED_PERCENTAGE (without executive experience) & & & $\begin{array}{c}-0.125 \\
(-0.893)\end{array}$ & \\
\hline AC_IED_PERCENTAGE (with financial expertise) & & & & $\begin{array}{l}-0.197^{\text {** }} \\
(-2.831)\end{array}$ \\
\hline AC_IED_PERCENTAGE (without financial expertise) & & & & $\begin{array}{c}0.026 \\
(0.181)\end{array}$ \\
\hline Control variables & Yes & Yes & Yes & Yes \\
\hline Firm fixed effects & Yes & Yes & Yes & Yes \\
\hline Year fixed effects & Yes & Yes & Yes & Yes \\
\hline Firm-year observations & 2,744 & 2,744 & 2,744 & 2,744 \\
\hline$R^{2}$ & 0.762 & 0.762 & 0.762 & 0.763 \\
\hline \multicolumn{5}{|l|}{$\underline{\text { Panel C. Irregularity }}$} \\
\hline AC_IED_PERCENTAGE (with recent 10-year experience) & $\begin{array}{l}-0.382^{\star \star} \\
(-2.273)\end{array}$ & & & \\
\hline AC_IED_PERCENTAGE (without recent 10-year experience) & $\begin{array}{c}0.187 \\
(0.485)\end{array}$ & & & \\
\hline AC_IED_PERCENTAGE (with public firm experience) & & $\begin{array}{c}-0.282 \\
(-1.260)\end{array}$ & & \\
\hline AC_IED_PERCENTAGE (without public firm experience) & & $\begin{array}{c}-0.165 \\
(-0.795)\end{array}$ & & \\
\hline AC_IED_PERCENTAGE (with executive experience) & & & $\begin{array}{c}-1.035 \\
(-1.620)\end{array}$ & \\
\hline AC_IED_PERCENTAGE (without executive experience) & & & $\begin{array}{c}-0.133 \\
(-0.952)\end{array}$ & \\
\hline AC_IED_PERCENTAGE (with financial expertise) & & & & $\begin{array}{l}-0.338^{*} \\
(-1.810)\end{array}$ \\
\hline AC_IED_PERCENTAGE (without financial expertise) & & & & $\begin{array}{c}0.474 \\
(0.680)\end{array}$ \\
\hline Control variables & Yes & Yes & Yes & Yes \\
\hline Industry fixed effects & Yes & Yes & Yes & Yes \\
\hline Year fixed effects & Yes & Yes & Yes & Yes \\
\hline Firm-year observations & 2,744 & 2,744 & 2,744 & 2,744 \\
\hline Pseudo- $R^{2}$ & 0.194 & 0.194 & 0.195 & 0.196 \\
\hline
\end{tabular}

of audit committee independent directors who have industry experience obtained from accounting-related positions (i.e., CFO, treasurer, controller, or comptroller) and the proportion of audit committee independent directors who have industry experience obtained solely from nonaccounting positions. We reestimate the abnormal accruals regression and present the results in column 4 of Panel A in Table 4. Consistent with our argument, we find that although independent director industry expertise acquired through both accounting and nonaccounting positions can significantly reduce earnings management, the magnitude of the 
coefficient on industry expertise gained through accounting positions is about twice as large.

We next repeat the previous analysis with the $F$-score as the dependent variable and present the results in Panel B of Table 4. The evidence echoes that in Panel A and suggests that independent director industry expertise is more effective at reducing the ex ante probability of financial misconduct when it is acquired more recently, from public firms, at the executive level, and through an accounting-related position. Finally, we examine whether various types of industry expertise possessed by independent directors have differential effects on a firm's probability of irregularity restatements. The results presented in Panel C of Table 4 are of the same tenor as those in Panels A and B, but slightly weaker. We find significant differential effects from independent director industry expertise only in the dimensions of how recent the experience is and whether the experience is obtained through an accounting-related position.

In summary, the evidence we present in this section as well as in the previous one highlights the importance of differentiating among firms, industries, and the nature of the industry experience. It demonstrates that not all firms in all industries can reap the monitoring benefits of independent director industry experience, and not all industry experience can enhance independent directors' capability to ensure high-quality financial reporting in the form of less earnings management.

\section{Endogeneity Correction via 2SLS Regressions}

In this section, as an alternative to the FFE specification, we address the endogeneity or omitted-variable problem by estimating 2SLS regressions in which we instrument the audit committee presence of IEDs with a variable based on both firm location and industry attributes. Specifically, the instrumental variable we choose for the presence of IEDs at a firm is specified as the logarithmic transformation of the number of other companies with which the firm shares the same first 3 digits of the zip code of the corporate headquarters location and the same 2-digit SIC code but not the same 4-digit SIC code. ${ }^{13}$ As we point out in the Introduction, this variable aims to capture the potential supply of local director candidates with relevant industry experience and is based on several stylized facts about the director-firm matching process. We expect that firms located close to a larger number of noncompeting industry peers are more likely to have a greater presence of independent directors with relevant industry experience on their boards.

Table 5 presents the 2 SLS regression results. In column 1, we estimate the first-stage regression, in which the dependent variable is AC_IED_PERCENTAGE. Consistent with our expectation, we find that IED presence on a firm's audit committee is significantly and positively related to the number of industry peer firms located nearby, indicating that our instrument satisfies the validity requirement. In columns 2-4, we estimate second-stage regressions in which the

\footnotetext{
${ }^{13}$ The logarithmic transformation is to remove the skewness in the original variable.
} 


\section{TABLE 5}

\section{SLS Regression of Earnings Management}

\begin{tabular}{|c|c|c|c|c|}
\hline & First Stage & ABSAA & F-Score & Irregularity \\
\hline Variables & 1 & 2 & 3 & 4 \\
\hline $\log (1+$ NUM_OF_NEARBY_PEER_FIRMS) & $\begin{array}{c}0.021^{*} \\
(1.835)\end{array}$ & & & \\
\hline Predicted AC_IED_PERCENTAGE & & $\begin{array}{l}-0.158^{\star \star \star} \\
(-2.726)\end{array}$ & $\begin{array}{l}-1.588^{* *} \\
(-2.285)\end{array}$ & $\begin{array}{l}-0.342^{\text {** }} \\
(-2.559)\end{array}$ \\
\hline FIRM_SIZE & $\begin{array}{c}-0.009 \\
(-0.777)\end{array}$ & $\begin{array}{c}0.000 \\
(0.264)\end{array}$ & $\begin{array}{l}0.048^{\star *} \\
(2.517)\end{array}$ & $\begin{array}{c}0.049 \\
(0.565)\end{array}$ \\
\hline FIRM_AGE & $\begin{array}{l}-0.003^{\star * *} \\
(-3.409)\end{array}$ & $\begin{array}{l}-0.001^{* *} \\
(-2.502)\end{array}$ & $\begin{array}{c}0.000 \\
(0.043)\end{array}$ & $\begin{array}{c}0.010 \\
(0.830)\end{array}$ \\
\hline LEVERAGE & $\begin{array}{l}-0.141^{\star *} \\
(-2.100)\end{array}$ & $\begin{array}{c}-0.010 \\
(-0.671)\end{array}$ & $\begin{array}{c}0.102 \\
(0.620)\end{array}$ & $\begin{array}{c}0.709 \\
(0.957)\end{array}$ \\
\hline TOBIN_Q & $\begin{array}{c}0.002 \\
(0.246)\end{array}$ & $\begin{array}{l}0.007^{\star \star *} \\
(4.353)\end{array}$ & $\begin{array}{l}-0.045^{\star \star *} \\
(-3.225)\end{array}$ & $\begin{array}{c}-0.080 \\
(-1.212)\end{array}$ \\
\hline $\mathrm{ROA}$ & $\begin{array}{c}-0.076 \\
(-0.953)\end{array}$ & $\begin{array}{l}-0.134^{\star \star \star} \\
(-5.923)\end{array}$ & $\begin{array}{c}0.183 \\
(1.083)\end{array}$ & $\begin{array}{c}-0.476 \\
(-0.785)\end{array}$ \\
\hline STD_SALES/ASSETS & $\begin{array}{l}-0.030 \\
(-0.307)\end{array}$ & $\begin{array}{l}0.058^{\text {*** }} \\
(4.359)\end{array}$ & $\begin{array}{l}0.311^{* *} \\
(2.444)\end{array}$ & $\begin{array}{l}0.503 \\
(0.954)\end{array}$ \\
\hline BOARD_SIZE & $\begin{array}{c}-0.001 \\
(-0.127)\end{array}$ & $\begin{array}{c}-0.001 \\
(-0.963)\end{array}$ & $\begin{array}{c}-0.002 \\
(-0.242)\end{array}$ & $\begin{array}{c}0.003 \\
(0.074)\end{array}$ \\
\hline BOARD_INDEPENDENCE & $\begin{array}{c}0.118 \\
(1.447)\end{array}$ & $\begin{array}{c}0.021 \\
(1.387)\end{array}$ & $\begin{array}{c}-0.171 \\
(-1.081)\end{array}$ & $\begin{array}{l}-1.499^{\star \star} \\
(-2.236)\end{array}$ \\
\hline CEO/CHAIRMAN & $\begin{array}{l}-0.033^{*} \\
(-1.743)\end{array}$ & $\begin{array}{c}-0.002 \\
(-0.402)\end{array}$ & $\begin{array}{c}0.027 \\
(0.690)\end{array}$ & $\begin{array}{c}0.174 \\
(0.934)\end{array}$ \\
\hline BOARD_BUSYNESS & $\begin{array}{c}-0.025 \\
(-0.525)\end{array}$ & $\begin{array}{c}-0.001 \\
(-0.181)\end{array}$ & $\begin{array}{c}-0.086 \\
(-1.027)\end{array}$ & $\begin{array}{c}0.277 \\
(0.750)\end{array}$ \\
\hline AC_SIZE & $\begin{array}{c}-0.004 \\
(-0.587)\end{array}$ & $\begin{array}{c}0.001 \\
(1.138)\end{array}$ & $\begin{array}{c}0.000 \\
(0.036)\end{array}$ & $\begin{array}{c}-0.464 \\
(-0.770)\end{array}$ \\
\hline AC_INDEPENDENCE & $\begin{array}{c}0.089 \\
(1.522)\end{array}$ & $\begin{array}{c}0.005 \\
(0.399)\end{array}$ & $\begin{array}{c}-0.026 \\
(-0.218)\end{array}$ & $\begin{array}{l}-0.084^{*} \\
(-1.654)\end{array}$ \\
\hline AC_BUSYNESS & $\begin{array}{l}0.177^{\star \star *} \\
(4.466)\end{array}$ & $\begin{array}{c}0.015 \\
(0.898)\end{array}$ & $\begin{array}{c}0.065 \\
(0.358)\end{array}$ & $\begin{array}{c}-0.970 \\
(-1.215)\end{array}$ \\
\hline AC_FIN_EXPERT_PERCENTAGE & $\begin{array}{c}0.094^{*} \\
(1.956)\end{array}$ & $\begin{array}{c}0.018 \\
(1.627)\end{array}$ & $\begin{array}{c}-0.042 \\
(-0.377)\end{array}$ & $\begin{array}{c}-0.509 \\
(-1.147)\end{array}$ \\
\hline AUDITOR_INDUSTRY_MARKET_SHARE & $\begin{array}{c}0.040 \\
(0.573)\end{array}$ & $\begin{array}{c}-0.010 \\
(-0.985)\end{array}$ & $\begin{array}{c}-0.137 \\
(-1.337)\end{array}$ & $\begin{array}{c}0.263 \\
(0.480)\end{array}$ \\
\hline CEO_INCENTIVE & $\begin{array}{c}0.001 \\
(0.018)\end{array}$ & $\begin{array}{l}-0.007 \\
(-1.193)\end{array}$ & $\begin{array}{c}0.056 \\
(0.908)\end{array}$ & $\begin{array}{c}0.028 \\
(0.100)\end{array}$ \\
\hline REPURCHASE_INCENTIVE & $\begin{array}{c}0.028^{* *} \\
(2.131)\end{array}$ & $\begin{array}{c}0.004 \\
(1.334)\end{array}$ & $\begin{array}{c}0.040 \\
(1.185)\end{array}$ & $\begin{array}{c}-0.204 \\
(-1.440)\end{array}$ \\
\hline SEO_INCENTIVE & $\begin{array}{c}-0.025 \\
(-0.954)\end{array}$ & $\begin{array}{c}-0.010 \\
(-1.555)\end{array}$ & $\begin{array}{c}0.001 \\
(0.024)\end{array}$ & $\begin{array}{c}0.209 \\
(0.806)\end{array}$ \\
\hline Constant & $\begin{array}{c}-0.059 \\
(-0.509)\end{array}$ & $\begin{array}{c}-0.017 \\
(-0.548)\end{array}$ & $\begin{array}{l}1.055^{\star \star} \\
(2.391)\end{array}$ & $\begin{array}{c}0.590 \\
(0.496)\end{array}$ \\
\hline $\begin{array}{l}\text { Industry fixed effects } \\
\text { Year fixed effects }\end{array}$ & $\begin{array}{l}\text { Yes } \\
\text { Yes }\end{array}$ & $\begin{array}{l}\text { Yes } \\
\text { Yes }\end{array}$ & $\begin{array}{l}\text { Yes } \\
\text { Yes }\end{array}$ & $\begin{array}{l}\text { Yes } \\
\text { Yes }\end{array}$ \\
\hline $\begin{array}{l}\text { Firm-year observations } \\
\text { Pseudo- } R^{2}\end{array}$ & $\begin{array}{r}2,744 \\
0.320\end{array}$ & $\begin{array}{l}2,744 \\
0.182\end{array}$ & $\begin{array}{l}2,744 \\
0.342\end{array}$ & $\begin{array}{r}2,744 \\
0.195\end{array}$ \\
\hline
\end{tabular}

dependent variable is ABSAA in column 2, F-score in column 3, and irregularity restatement in column 4 , and the key independent variable is the predicted value of AC_IED_PERCENTAGE based on the first-stage coefficient estimates. 
The results show that the presence of IEDs on the audit committee continues to have a significantly negative effect on earnings management. This provides further assurance that our results are at least not entirely driven by endogeneity or omitted variables.

\section{Independent Director Industry Expertise and Other Corporate Policies}

So far we have focused on the effect of industry expertise on independent directors' monitoring effectiveness in the domain of corporate financial reporting. Although high-quality financial reporting is a key responsibility of boards and a top priority for regulators in their efforts to protect investors and improve capital allocation in the economy, board monitoring is also important in many other aspects of corporate decision making. In this section, we examine whether the presence of IEDs is related to the board's monitoring effectiveness in firm policies involving CEO compensation, corporate acquisition, and CEO turnover.

\section{A. CEO Compensation}

We first examine whether independent director industry expertise affects the level of CEO compensation. Executive compensation policy is one of the most important decisions for boards, and weak board monitoring is often associated with exorbitant CEO compensation. According to the expert monitor hypothesis, we expect the presence of IEDs on a firm's board to help avoid overpaying the $\mathrm{CEO}$, to the extent that independent directors equipped with relevant industry expertise are able to better understand industry-specific characteristics and trends that determine a fair and competitive level of executive compensation. However, the compromised monitor hypothesis predicts a positive relation between the presence of IEDs and CEO excess compensation, because independent directors who are connected or sympathetic to the CEO are likely to award the CEO an overly generous compensation package.

To test these competing predictions, we merge our director expertise sample with the ExecuComp database to obtain CEO compensation information. To the extent that compensation committees (CCs) are primarily in charge of setting executive pay level and structure, we focus on the presence of IEDs on a firm's CC. The average (median) firm in our sample has a CC_IED_PERCENTAGE of 0.25 (0.20). We estimate two regressions of CEO compensation level against the presence of IEDs on the $\mathrm{CC}$ while controlling for other firm financial and governance characteristics. The regression results are presented in Table 6.

The dependent variable is the level of total CEO compensation in logarithmic transformation in column 1 and excess CEO compensation in column 2. We follow previous studies, such as Cai, Garner, and Walkling (2009), in estimating CEO excess compensation. Specifically, we use all ExecuComp firm-year observations during 2000-2007 and estimate an ordinary least squares (OLS) regression of the logarithmic transformation of total CEO compensation (ExecuComp item TDC1) on firm size, fiscal year buy-and-hold abnormal return, stock return volatility, and industry and year fixed effects. The residual of the regression 
TABLE 6

Regression Analysis of CEO Compensation

\begin{tabular}{|c|c|c|}
\hline & CEO_COMPENSATION & CEO_EXCESS_COMPENSATION \\
\hline Variables & 1 & 2 \\
\hline CC_IED_PERCENTAGE & $\begin{array}{l}-0.240^{* *} \\
(-1.976)\end{array}$ & $\begin{array}{l}-0.244^{\star *} \\
(-2.020)\end{array}$ \\
\hline FIRM_SIZE & $\begin{array}{l}0.367^{\star \star \star} \\
(2.907)\end{array}$ & $\begin{array}{l}-0.099 \\
(-0.989)\end{array}$ \\
\hline FIRM_AGE & $\begin{array}{c}0.182 \\
(0.396)\end{array}$ & $\begin{array}{c}0.239 \\
(0.586)\end{array}$ \\
\hline LEVERAGE & $\begin{array}{l}-0.566^{\star * *} \\
(-2.592)\end{array}$ & $\begin{array}{l}-0.508^{\star *} \\
(-2.429)\end{array}$ \\
\hline TOBIN_Q & $\begin{array}{l}0.102 \\
(1.557)\end{array}$ & $\begin{array}{c}0.023 \\
(0.435)\end{array}$ \\
\hline ROA & $\begin{array}{l}-0.032 \\
(-0.091)\end{array}$ & $\begin{array}{c}0.139 \\
(0.435)\end{array}$ \\
\hline BHAR & $\begin{array}{c}0.024 \\
(0.345)\end{array}$ & $\begin{array}{l}-0.093 \\
(-1.425)\end{array}$ \\
\hline LAGGED_BHAR & $\begin{array}{l}0.197^{* * *} \\
(3.664)\end{array}$ & $\begin{array}{c}0.037 \\
(0.731)\end{array}$ \\
\hline STD_SALES/ASSETS & $\begin{array}{r}0.513^{*} \\
(1.882)\end{array}$ & $\begin{array}{c}0.396 \\
(1.541)\end{array}$ \\
\hline BOARD_SIZE & $\begin{array}{l}-0.010 \\
(-0.632)\end{array}$ & $\begin{array}{l}-0.008 \\
(-0.533)\end{array}$ \\
\hline BOARD_INDEPENDENCE & $\begin{array}{c}0.259 \\
(1.159)\end{array}$ & $\begin{array}{c}0.243 \\
(1.099)\end{array}$ \\
\hline CEO/CHAIRMAN & $\begin{array}{c}0.079 \\
(1.343)\end{array}$ & $\begin{array}{c}0.079 \\
(1.391)\end{array}$ \\
\hline BOARD_BUSYNESS & $\begin{array}{c}0.017 \\
(0.113)\end{array}$ & $\begin{array}{c}0.029 \\
(0.217)\end{array}$ \\
\hline Constant & $\begin{array}{l}-1.605 \\
(-0.090)\end{array}$ & $\begin{array}{l}-8.257 \\
(-0.522)\end{array}$ \\
\hline $\begin{array}{l}\text { Firm fixed effects } \\
\text { Year fixed effects }\end{array}$ & $\begin{array}{l}\text { Yes } \\
\text { Yes }\end{array}$ & $\begin{array}{l}\text { Yes } \\
\text { Yes }\end{array}$ \\
\hline $\begin{array}{l}\text { Firm-year observations } \\
R^{2}\end{array}$ & $\begin{array}{l}2,727 \\
0.594\end{array}$ & $\begin{array}{l}2,727 \\
0.470\end{array}$ \\
\hline
\end{tabular}

is our measure of CEO excess compensation. We regress CEO (excess) compensation on the percentage of IEDs on the compensation committee (CC_IED_ PERCENTAGE). Results in columns 1 and 2 of Table 6 show that CC_IED_ PERCENTAGE is associated with a significantly lower level of CEO (excess) compensation, lending support to the expert monitor hypothesis.

In addition to the level of CEO compensation, we also examine the impact of industry expert directors on CEO equity incentives from compensation. We measure $\mathrm{CEO}$ equity incentives by the dollar-value change in $\mathrm{CEO}$ wealth with respect to a $1 \%$ change in stock price estimated using the methodology in Core and Guay (2002). Unreported regression results indicate that CC_IED_PERCENTAGE does not appear to be significantly related to CEO equity incentives. This could reflect the confluence of two forces with offsetting effects on CEO equity incentives. More effective board monitoring enabled by independent director industry expertise may be a substitute for CEO incentive compensation, and, at the same time, 
corporate boards with strong monitors may demand a higher sensitivity of CEO wealth to shareholder value.

\section{B. CEO Turnover-Performance Sensitivity}

In this section, we examine how the presence of IEDs affects the effectiveness of boards in disciplining poorly performing CEOs, because evaluating managerial performance and replacing underperforming CEOs is one of the major responsibilities of boards. The expert monitor hypothesis predicts that boards with a greater IED presence are more likely to replace underperforming CEOs in a timely fashion, because having relevant industry experience enables directors to more accurately assess the CEO's decision making and performance, and, in the event of a CEO firing, to help manage the company until a replacement is identified and hired. The compromised monitor hypothesis, however, suggests that independent directors with industry experience may be connected with the CEO or sympathetic to the CEO because of overlapping or similar background and thus are less likely to instigate or support management changes in response to poor firm performance.

To examine these possibilities, we use the BoardEx database to identify all CEO turnover events between 2000 and 2007 for our sample firms. For each firm, a CEO turnover event occurs if the executive listed as the CEO in any year is different from the CEO listed for the previous year. We then identify the date and cause of the CEO turnover through a Lexis/Nexis news search. Following previous studies (e.g., Parrino (1997), Huson, Parrino, and Starks (2001), Parrino, Sias, and Starks (2003), and Huson, Malatesta, and Parrino (2004)), a CEO turnover is classified as forced if it is not due to any of the following reasons: death, health problem, normal retirement (when the CEO is 60 years old or older, or the retirement is announced at least 6 months prior to the CEO turnover), and moving to a higher/comparable level position at another firm. We exclude CEO turnover events due to mergers, acquisitions, or spin-offs. Firm-year observations involving interim CEOs or co-CEOs are also deleted. We observe $282 \mathrm{CEO}$ turnover events for our sample firms during our sample period, with 70 of them classified as forced.

To examine whether the presence of IEDs is related to the sensitivity of forced CEO turnovers to firm performance, we partition our sample into two subsamples based on whether a firm's BOARD_IED_PERCENTAGE is above or below the sample median and estimate probit regressions of CEO turnovers separately in the subsamples. Table 7 reports regression results, with column 1 for the subsample with above-sample-median BOARD_IED_PERCENTAGE and column 2 for the subsample with below-sample-median BOARD_IED_ PERCENTAGE. The dependent variable is set equal to 1 for firm-years in which a forced CEO turnover event takes place, and 0 otherwise. We measure a firm's performance by its industry-adjusted ROA over the previous fiscal year. We use accounting returns rather than stock returns as our performance metric because the latter also incorporate the probability of future CEO turnovers, and thus suffers from a look-ahead bias (Weisbach (1988)). Consistent with prior studies (see, e.g., Coughlan and Schmidt (1985), Weisbach (1988), and Fich and Shivdasani 
TABLE 7

Probit Analysis of CEO Turnover-Performance Sensitivity

\begin{tabular}{|c|c|c|}
\hline & High BOARD_IED_PERCENTAGE & Low BOARD_IED_PERCENTAGE \\
\hline Variables & 1 & \\
\hline $\mathrm{ROA}$ & $\begin{array}{l}-2.078^{*} \\
(-1.729)\end{array}$ & $\begin{array}{l}-1.880 \\
(-1.487)\end{array}$ \\
\hline FIRM_SIZE & $\begin{array}{c}0.091 \\
(1.048)\end{array}$ & $\begin{array}{l}-0.015 \\
(-0.126)\end{array}$ \\
\hline FIRM_AGE & $\begin{array}{l}-0.008 \\
(-1.436)\end{array}$ & $\begin{array}{l}-0.000 \\
(-0.032)\end{array}$ \\
\hline LEVERAGE & $\begin{array}{c}0.975 \\
(1.584)\end{array}$ & $\begin{array}{l}0.517 \\
(0.581)\end{array}$ \\
\hline TOBIN_Q & $\begin{array}{l}-0.151 \\
(-1.397)\end{array}$ & $\begin{array}{l}-0.419^{\star *} \\
(-2.254)\end{array}$ \\
\hline STD_SALES/ASSETS & $\begin{array}{l}-0.021 \\
(-0.030)\end{array}$ & $\begin{array}{l}0.747 \\
(0.607)\end{array}$ \\
\hline BOARD_SIZE & $\begin{array}{l}-0.012 \\
(-0.281)\end{array}$ & $\begin{array}{l}0.090^{* *} \\
(2.168)\end{array}$ \\
\hline BOARD_INDEPENDENCE & $\begin{array}{c}0.298 \\
(0.521)\end{array}$ & $\begin{array}{l}-0.679 \\
(-0.938)\end{array}$ \\
\hline CEO/CHAIRMAN & $\begin{array}{c}0.063 \\
(0.361)\end{array}$ & $\begin{array}{l}-0.525^{\star *} \\
(-2.229)\end{array}$ \\
\hline BOARD_BUSYNESS & $\begin{array}{l}-0.805^{\star *} \\
(-2.120)\end{array}$ & $\begin{array}{c}0.903 \\
(1.520)\end{array}$ \\
\hline BOARD_IED_PERCENTAGE & $\begin{array}{l}-0.424 \\
(-1.002)\end{array}$ & $\begin{array}{c}0.891 \\
(0.569)\end{array}$ \\
\hline Constant & $\begin{array}{l}-10.335^{* * *} \\
(-10.761)\end{array}$ & $\begin{array}{l}-11.050^{* * *} \\
(-9.806)\end{array}$ \\
\hline $\begin{array}{l}\text { Industry fixed effects } \\
\text { Year fixed effects }\end{array}$ & $\begin{array}{l}\text { Yes } \\
\text { Yes }\end{array}$ & $\begin{array}{l}\text { Yes } \\
\text { Yes }\end{array}$ \\
\hline $\begin{array}{l}\text { Firm-year observations } \\
\text { Pseudo- } R^{2}\end{array}$ & $\begin{array}{l}1,465 \\
0.219\end{array}$ & $\begin{array}{l}1,384 \\
0.331\end{array}$ \\
\hline
\end{tabular}

(2006)), we find that the probability of forced CEO turnovers is negatively related to the industry-adjusted ROA, indicating that poorly performing CEOs are more likely to be terminated. However, the relation is statistically significant only when a firm's percentage of IEDs on the board is above the sample median. This evidence supports the expert monitor hypothesis and suggests that boards with more IEDs are more likely to remove poorly performing CEOs.

\section{Corporate Acquisitions}

In this section, we examine how relevant industry expertise possessed by independent directors is related to firms' returns when they make acquisitions. Acquisitions are often the largest investments a firm ever undertakes. Prior studies have shown that self-interested managers are prone to making empire-building acquisitions as a way to extract personal benefits at the expenses of shareholders. Even when managers' interests are aligned with those of shareholders, acquiring firms often fall into the trap of overpaying when they are uncertain about the true value of target firms due to heightened information asymmetry. As a departure 
from previous sections, the relevant industry expertise we focus on in the acquisition analysis is the experience from the target firm's industry, because directors need to have a good understanding of the target's industry in order to evaluate the merits of a proposed acquisition, especially when the acquisition is diversifying and involves a target from a different industry than that of the acquirer. Of course, when an acquisition is within industry, target industry expertise is the same as acquirer industry expertise, and our measure of IED presence on corporate boards is the same as that used in the previous analyses. The expert monitor hypothesis predicts that the presence of IEDs enhances board monitoring, curbs managers' empire-building activities, and improves acquiring shareholders' returns from acquisitions. However, the compromised monitor hypothesis predicts that the presence of IEDs weakens board oversight of firms' major investment decisions and allows CEOs to engage in shareholder-value-destroying acquisitions.

To test these conjectures, we obtain from the Securities Data Corporation's (SDC) Mergers and Acquisitions Database a sample of 762 acquisitions made by our sample companies during our sample period. For each deal, we require that i) the deal value disclosed by the SDC is more than $\$ 1$ million and at least $1 \%$ of the acquirer's market value of equity at the fiscal year end prior to the deal announcement; ii) the acquirer has annual financial statement information available from Compustat for the year prior to the deal announcement, and has stock return data available from CRSP for the period from 210 trading days prior to the deal announcement to 5 trading days afterward; and iii) the acquirer controls less than $50 \%$ of target shares prior to the deal announcement and owns $100 \%$ of the target afterward.

Following Moeller, Schlingemann, and Stulz (2004), we measure an acquirer's performance by its cumulative abnormal returns (CARs) over the 3-day event window $(-1,+1)$, where date 0 is the announcement date taken from the SDC. The average CAR for our sample acquirers is $-0.454 \%$ and the median is $-0.351 \%$. Both are significantly different from 0 at the $1 \%$ level. Because our acquirers are among the largest 500 firms as measured by the market value of equity, the negative average (median) CAR is consistent with the negative effect of firm size on acquirer returns documented in Moeller et al. (2004). We estimate OLS regressions of acquirer CARs in which we control for a wide array of acquirer characteristics and deal characteristics. We present the regression results in Table 8.

In column 1 of Table 8, our key explanatory variable, the percentage of independent directors with target industry expertise, has a positive, but insignificant coefficient. The indicator variable for diversifying acquisitions has a negative coefficient estimate that is significant at the $1 \%$ level, consistent with Morck et al.'s (1990) argument that diversifying acquisitions often benefit managers while at the same time resulting in shareholder value losses. In light of this finding, and the fact that acquirers face more obstacles when venturing into an unrelated industry, we interact the BOARD_IED_PERCENTAGE variable with the indicator for diversifying acquisitions and include it as an additional explanatory variable in the acquirer return regression. Our conjecture is that independent directors with expertise from the target's industry play an important role in preventing 
TABLE 8

Regression Analysis of Acquirer Returns

\begin{tabular}{|c|c|c|}
\hline Variables & 1 & 2 \\
\hline BOARD_IED_PERCENTAGE_(TARGET_INDUSTRY) & $\begin{array}{l}0.200 \\
(0.207)\end{array}$ & $\begin{array}{l}-1.319 \\
(1.097)\end{array}$ \\
\hline $\begin{array}{l}\text { BOARD_IED_PERCENTAGE_(TARGET INDUSTRY) } \times \\
\text { DIVERSIFYING_ACQUISITION }\end{array}$ & & $\begin{array}{l}3.986^{* \star *} \\
(2.666)\end{array}$ \\
\hline $\begin{array}{l}\text { Deal Characteristics } \\
\text { DIVERSIFYING_ACQUISITION }\end{array}$ & $\begin{array}{l}-1.371^{* \star *} \\
(3.553)\end{array}$ & $\begin{array}{l}-2.092^{\star * \star} \\
(4.499)\end{array}$ \\
\hline RELATIVE_DEAL_SIZE & $\begin{array}{l}-2.982^{\star \star *} \\
(3.686)\end{array}$ & $\begin{array}{l}-2.836^{\star \star \star} \\
(3.580)\end{array}$ \\
\hline PUBLIC_TARGET & $\begin{array}{l}-1.064^{\star \star} \\
(2.367)\end{array}$ & $\begin{array}{c}-1.118^{\star \star} \\
(2.515)\end{array}$ \\
\hline PRIVATE_TARGET & $\begin{array}{r}-0.052 \\
(0.112)\end{array}$ & $\begin{array}{c}0.004 \\
(0.008)\end{array}$ \\
\hline PERCENTAGE_OF_DEAL_VALUE_PAID_WITH_ACQUIRER_STOCK & $\begin{array}{l}-0.022^{* * *} \\
(3.097)\end{array}$ & $\begin{array}{l}-0.021^{\star \star \star} \\
(3.093)\end{array}$ \\
\hline HOSTILE_DEAL & $\begin{array}{c}1.036 \\
(0.471)\end{array}$ & $\begin{array}{l}1.077 \\
(0.494)\end{array}$ \\
\hline TENDER_OFFER & $\begin{array}{c}0.251 \\
(0.281)\end{array}$ & $\begin{array}{l}0.311 \\
(0.343)\end{array}$ \\
\hline COMPETED_DEAL & $\begin{array}{c}1.862 \\
(1.434)\end{array}$ & $\begin{array}{c}1.778 \\
(1.370)\end{array}$ \\
\hline $\begin{array}{l}\text { Acquirer Characteristics } \\
\text { FIRM_SIZE }\end{array}$ & $\begin{array}{l}-0.570^{\star \star} \\
(2.438)\end{array}$ & $\begin{array}{c}-0.546^{\star \star} \\
(2.348)\end{array}$ \\
\hline FIRM_AGE & $\begin{array}{c}0.000 \\
(0.036)\end{array}$ & $\begin{array}{c}0.003 \\
(0.256)\end{array}$ \\
\hline LEVERAGE & $\begin{array}{c}0.484 \\
(0.320)\end{array}$ & $\begin{array}{c}0.646 \\
(0.427)\end{array}$ \\
\hline TOBIN_Q & $\begin{array}{l}0.104 \\
(0.521)\end{array}$ & $\begin{array}{c}0.109 \\
(0.536)\end{array}$ \\
\hline $\mathrm{ROA}$ & $\begin{array}{c}-0.446 \\
(0.146)\end{array}$ & $\begin{array}{c}-0.773 \\
(0.253)\end{array}$ \\
\hline BOARD_SIZE & $\begin{array}{l}-0.047 \\
(0.621)\end{array}$ & $\begin{array}{c}-0.064 \\
(0.838)\end{array}$ \\
\hline BOARD_INDEPENDENCE & $\begin{array}{l}-0.971 \\
(0.605)\end{array}$ & $\begin{array}{c}-0.883 \\
(0.551)\end{array}$ \\
\hline CEO/CHAIRMAN & $\begin{array}{c}-0.210 \\
(0.530)\end{array}$ & $\begin{array}{c}-0.275 \\
(0.694)\end{array}$ \\
\hline BOARD_BUSYNESS & $\begin{array}{c}1.103 \\
(1.005)\end{array}$ & $\begin{array}{c}1.099 \\
(0.997)\end{array}$ \\
\hline Constant & $\begin{array}{c}0.841 \\
(0.387)\end{array}$ & $\begin{array}{l}0.910 \\
(0.421)\end{array}$ \\
\hline $\begin{array}{l}\text { Industry fixed effects } \\
\text { Year fixed effects }\end{array}$ & $\begin{array}{l}\text { Yes } \\
\text { Yes }\end{array}$ & $\begin{array}{l}\text { Yes } \\
\text { Yes }\end{array}$ \\
\hline $\begin{array}{l}\text { Firm-year observations } \\
R^{2}\end{array}$ & $\begin{array}{c}762 \\
0.124\end{array}$ & $\begin{array}{c}762 \\
0.130\end{array}$ \\
\hline
\end{tabular}

shareholder-value-destroying acquisitions when the potential for shareholder value destruction is greater.

The results in column 2 of Table 8 show that the interaction term has a positive and significant coefficient estimate. This finding is consistent with the expert monitor hypothesis and suggests that expertise in the target's industry allows independent directors to better evaluate diversifying acquisitions and 
prevent shareholder-value-destroying deals. ${ }^{14}$ In fact, based on the coefficients presented in column 2, when $50 \%$ of independent directors on the acquirer's board have expertise in the target's industry, the significantly negative effect of diversifying acquisitions on acquirer returns largely disappears.

With respect to the control variables, we find that acquirer returns are significantly lower when the acquirer is larger, the target is a public company, the relative deal size is greater, and a higher percentage of deal value is paid in acquirer stock. These results are consistent with the existing findings in the mergers and acquisitions (M\&A) literature (e.g., Andrade, Mitchell, and Stafford (2001), Moeller et al. (2004)).

\section{Conclusion}

The efficacy of the functioning of corporate boards as a governance mechanism has been a subject of significant interest to lawmakers, regulators, and investors, as well as governance scholars. A large body of academic research has sought to evaluate whether independent directors contribute to board effectiveness, with much of the investigation focusing on directors' attributes that affect their independence from firm management. However, relatively little attention has been paid to the characteristics of independent directors that may affect their capability to perform their duties.

In this paper, we examine the industry expertise obtained by independent directors through their prior employment as a determinant of their capability. We find that possessing knowledge and expertise about the industries of the firms they serve enhances independent directors' ability to perform their monitoring function. Specifically, we find that the presence of independent directors with industry experience on a firm's audit committee significantly curtails firms' earnings management via abnormal accruals, and reduces both ex ante and ex post probabilities of firms committing financial misconduct. This is consistent with the hypothesis that industry experience enables independent directors to better understand, evaluate, and thus monitor and improve firms' financial reporting.

We also uncover evidence that relevant industry experience significantly enhances boards' monitoring effectiveness in other key areas of corporate policies and decision making. More specifically, we find that a greater representation of independent directors with industry expertise on a firm's compensation committee reduces excess CEO compensation, and a greater presence of such directors on the full board increases the CEO turnover-performance sensitivity and improves acquirer returns from diversifying acquisitions.

\section{Appendix. Variable Definitions}

We list the definitions of all variables in Table A1.

\footnotetext{
${ }^{14}$ We acknowledge that this evidence can also be explained by directors with relevant industry expertise performing a more effective advisory function and improving acquirer performance in diversifying acquisitions.
} 
TABLE A1

Variable Definitions

Variable
Financial Variables
FIRM_SIZE
FIRM_AGE
LEVERAGE
TOBIN_Q
ROA
STD_SALES/ASSETS
BHAR
Board Characteristics
BOARD_SIZE
BOARD_INDEPENDENCE
CEO/CHAIRMAN
BOARD_BUSYNESS

BOARD_IED_PERCENTAGE

AC_SIZE

AC_INDEPENDENCE

AC_BUSYNESS

AC_IED_PERCENTAGE

AC_FIN_EXPERT_PERCENTAGE

CC_IED_PERCENTAGE

BOARD_IED_PERCENTAGE_ (TARGET_INDUSTRY)

Additional Variables IDIOSYNCRATIC_VOLATILITY

INDUSTRY_HOMOGENEITY

$\log (1+$ NUM_OF_NEARBY_PEER FIRMS)

AUDITOR_INDUSTRY_MARKET_SHARE

CEO_INCENTIVE

REPURCHASE_INCENTIVE

\begin{tabular}{|c|c|}
\hline Definition & Source \\
\hline $\begin{array}{l}\text { Log of total value of assets, in millions of U.S. dollars } \\
\text { (item 6). }\end{array}$ & Compusta \\
\hline $\begin{array}{l}\text { Firm age, which is the number of years since a firm's } \\
\text { first appearance in Compustat. }\end{array}$ & Compusta \\
\hline $\begin{array}{l}\text { Long-term plus short-term debt, scaled by total assets } \\
\text { ((item } 9+\text { item 34)/item 6). }\end{array}$ & Compusta \\
\hline $\begin{array}{l}\text { Market-to-book ratio, which is book value of assets, } \\
\text { less book value of equity, plus market value of } \\
\text { equity, scaled by total assets ((item } 6+\text { (item } 199 \\
\quad \times \text { item 25) - item } 60 \text { - item 74)/item 6). }\end{array}$ & Compusta \\
\hline $\begin{array}{l}\text { Return on assets, which is earnings divided by total } \\
\text { assets (item 18/item 6). }\end{array}$ & Compusta \\
\hline $\begin{array}{l}\text { Standard deviation of sales scaled by assets (item } \\
12 / \text { item } 6 \text { ) over the previous } 5 \text { years. }\end{array}$ & Compusta \\
\hline $\begin{array}{l}\text { Fiscal year buy-and-hold return minus CRSP value- } \\
\text { weighted-index buy-and-hold return. }\end{array}$ & Compusta \\
\hline $\begin{array}{l}\text { Number of board members. } \\
\text { Number of independent directors divided by total } \\
\text { number of directors. }\end{array}$ & $\begin{array}{l}\text { BoardEx } \\
\text { BoardEx }\end{array}$ \\
\hline
\end{tabular}

Dummy variable that is equal to 1 if the CEO is the BoardEx chairman of the board, and 0 otherwise.

Number of independent directors who hold three or more directorships at publicly traded firms divided by total number of independent directors.

Number of independent directors with industry expertise divided by total number of independent directors on the board.

Number of audit committee members.

Number of independent audit committee members divided by total number of audit committee members.

Number of independent audit committee members who hold three or more directorships at publicly traded firms divided by total number of independent audit committee members.

Number of independent directors on audit committee with industry expertise divided by total number of independent directors on audit committee.

Number of financial experts on audit committee divided by total number of independent audit committee members.

Number of independent directors on compensation committee with industry expertise divided by total number of independent directors on compensation committee.

Number of acquirer independent directors with target industry expertise divided by total number of independent directors on the acquirer's board.

Excess stock return volatility, which is the standard deviation of fiscal year daily excess stock return, calculated from the Fama-French (1992) 3-factor model.

Stock return correlation of firms in the same 2-digit SIC industry.

Log of 1 plus the number of all firms in the same 2-digit but not same 4-digit SIC industry in the 3-digit zip code neighborhood.

Sales of an auditor's clients in a 2-digit SIC industry divided by the total sales of all firms in the industry.

Delta/(delta + cash compensation), where delta is the dollar-value change in the CEO's stock and option portfolio per $1 \%$ increase in stock price (Core and Guay (2002)) and cash compensation is equal to salary plus bonus.

Indicator variable that is equal to 1 if a firm makes an open-market stock repurchase in the next fiscal year, and 0 otherwise.
BoardEx

BoardEx

BoardEx

BoardEx

BoardEx

BoardEx

BoardEx

BoardEx

BoardEx

CRSP

CRSP

Compustat

Compustat

Compustat

SDC 
TABLE A1 (continued)

Variable Definitions

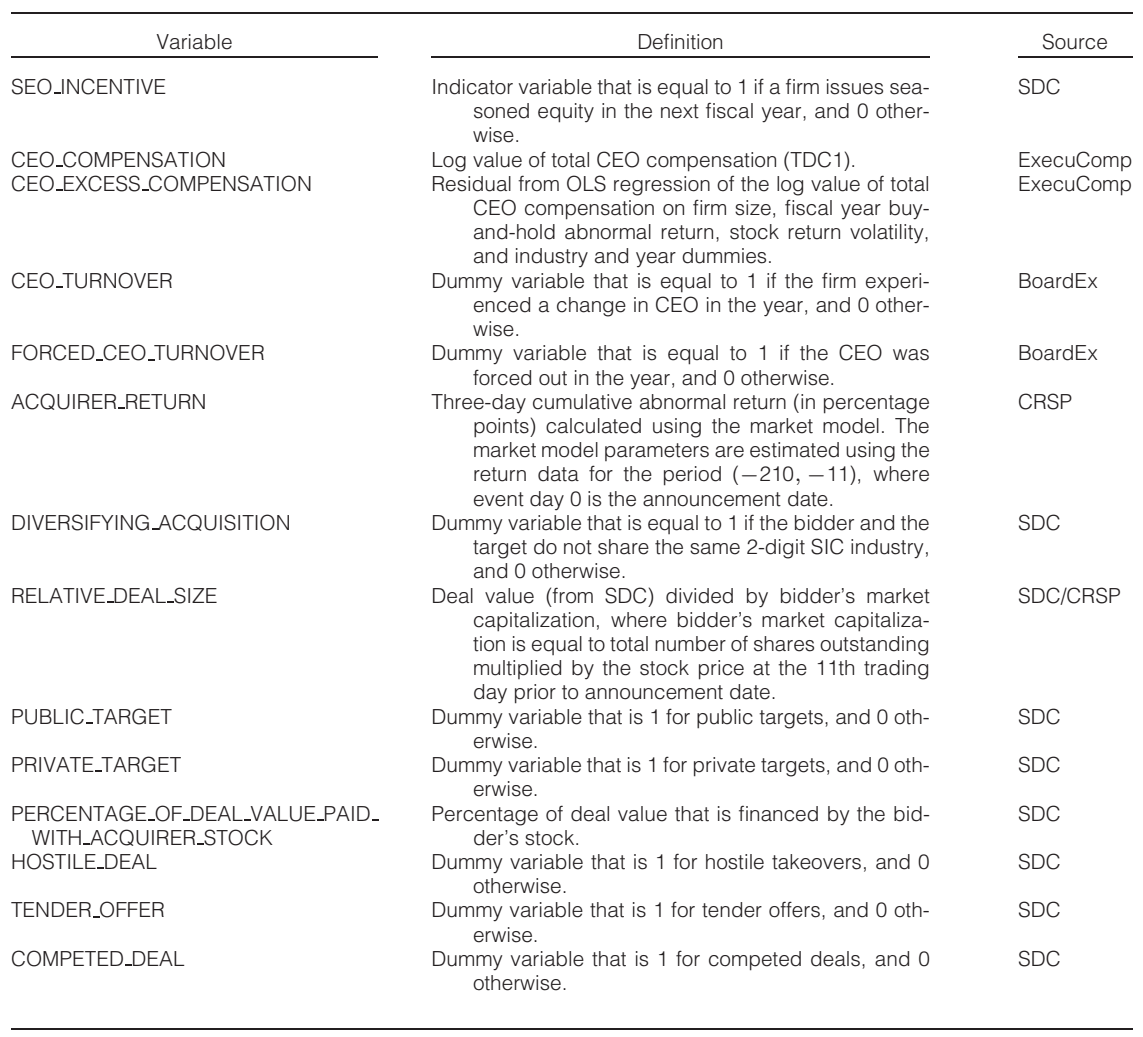

\section{References}

Adams, R., and D. Ferreira. "A Theory of Friendly Boards.” Journal of Finance, 62 (2007), 217-250.

Adams, R.; B. Hermalin; and M. Weisbach. "The Role of Boards of Directors in Corporate Governance: A Conceptual Framework and Survey." Journal of Economic Literature, 48 (2010), 58-107.

Agrawal, A., and S. Chadha. "Corporate Governance and Accounting Scandals." Journal of Law and Economics, 48 (2005), 371-406.

Andrade, G.; M. Mitchell; and E. Stafford. "New Evidence and Perspectives on Mergers." Journal of Economic Perspectives, 15 (2001), 103-120.

Bergstresser, D., and T. Philippon. "CEO Incentives and Earnings Management.” Journal of Financial Economics, 80 (2006), 511-529.

Burgstahler, D.; L. Hail; and C. Leuz. "The Importance of Reporting Incentives: Earnings Management in European Private and Public Firms." Accounting Review, 81 (2006), 983-1016.

Cai, J.; J. Garner; and R. Walkling. "Electing Directors.” Journal of Finance, 64 (2009), 2389-2421.

Cheng, Q., and T. Warfield. "Equity Incentives and Earnings Management." Accounting Review, 80 (2005), 441-476.

Cohen, D.; A. Dey; and T. Lys. "Real and Accrual-Based Earnings Management in the Pre- and PostSarbanes-Oxley Periods." Accounting Review, 83 (2008), 757-787.

Core, J., and W. Guay. "Estimating the Value of Employee Stock Option Portfolios and Their Sensitivities to Price and Volatility." Journal of Accounting Research, 40 (2002), 613-630.

Coughlan, A., and R. Schmidt. "Executive Compensation, Management Turnover, and Firm Performance: An Empirical Investigation.” Journal of Accounting and Economics, 7 (1985), 43-66. 
Dass, N.; O. Kini; V. Nanda; B. Onal; and J. Wang. "Board Expertise: Do Directors from Related Industries Help Bridge the Information Gap?” Review of Financial Studies, 27 (2014), 1533-1592.

Dechow, P.; W. Ge; C. Larson; and R. Sloan. "Predicting Material Accounting Misstatements." Contemporary Accounting Research, 28 (2011), 17-82.

Dechow, P.; W. Ge; and C. Schrand. "Understanding Earnings Quality: A Review of the Proxies, Their Determinants and Their Consequences." Journal of Accounting and Economics, 50 (2010), 344-401.

Dechow, P.; R. Sloan; and A. Sweeney. "Detecting Earnings Management.” Accounting Review, 70 (1995), 193-225.

Dechow, P.; R. Sloan; and A. Sweeney. "Causes and Consequences of Earnings Manipulation: An Analysis of Firms Subject to Enforcement Actions by the SEC." Contemporary Accounting Research, 12 (1996), 1-36.

DeFond, M.; R. Hann; and X. Hu. "Does the Market Value Financial Expertise on Audit Committees of Boards of Directors?" Journal of Accounting Research, 43 (2005), 153-193.

Dhaliwal, D.; V. Naiker; and F. Navissi. "The Association between Accruals Quality and the Characteristics of Accounting Experts and Mix of Expertise on Audit Committees." Contemporary Accounting Research, 27 (2010), 787-827.

Dichev, I.; J. Graham; C. Harvey; and S. Rajgopal. "Earnings Quality: Evidence from the Field." Journal of Accounting and Economics, 56 (2013), 1-33.

Duchin, R.; J. Matsusaka; and O. Ozbas. "When Are Outside Directors Effective?" Journal of Financial Economics, 96 (2010), 195-214.

Fama, E., and K. French. "The Cross-Section of Expected Stock Returns." Journal of Finance, 47 (1992), 427-465.

Fernandes, N., and E. Fich. “ Does Financial Experience Help Banks during Credit Crises?” Working Paper, Drexel University (2012).

Fich, E., and A. Shivdasani. "Are Busy Boards Effective Monitors?” Journal of Finance, 61 (2006), 689-724.

Fich, E., and A. Shivdasani. "Financial Fraud, Director Reputation, and Shareholder Wealth." Journal of Financial Economics, 86 (2007), 306-336.

Gong, G.; H. Louis; and A. Sun. "Earnings Management and Firm Performance Following OpenMarket Repurchases.” Journal of Finance, 63 (2008), 947-986.

Guner, A.; U. Malmendier; and G. Tate. "Financial Expertise of Directors." Journal of Financial Economics, 88 (2008), 323-354.

Harris, M., and A. Raviv. "A Theory of Board Control and Size." Review of Financial Studies, 21 (2008), 1797-1832.

Hazarika, S.; J. Karpoff; and R. Nahata. "Internal Corporate Governance, CEO Turnover, and Earnings Management.” Journal of Financial Economics, 104 (2012), 44-69.

Hennes, K.; A. Leone; and B. Miller. "The Importance of Distinguishing Errors from Irregularities in Restatement Research: The Case of Restatements and CEO/CFO Turnover." Accounting Review, 83 (2008), 1487-1519.

Hermalin, B., and M. Weisbach. "Boards of Directors as an Endogenously Determined Institution: A Survey of the Economic Literature.” Economic Policy Review, 9 (2003), 7-26.

Huson, M.; P. Malatesta; and R. Parrino. "Managerial Succession and Firm Performance." Journal of Financial Economics, 74 (2004), 237-275.

Huson, M.; R. Parrino; and L. Starks. "Internal Monitoring Mechanisms and CEO Turnover: A LongTerm Perspective.” Journal of Finance, 56 (2001), 2265-2297.

Jones, J. "Earnings Management during Import Relief Investigations." Journal of Accounting Research, 29 (1991), 193-228.

Karpoff, J.; D. Lee; and G. Martin. "The Cost to Firms of Cooking the Books.” Journal of Financial and Quantitative Analysis, 43 (2008), 581-611.

Klein, A. "Audit Committee, Board of Director Characteristics, and Earnings Management." Journal of Accounting and Economics, 33 (2002), 375-400.

Knyazeva, A.; D. Knyazeva; and R. Masulis. "The Supply of Corporate Directors and Board Independence." Review of Financial Studies, 26 (2013), 1561-1605.

Kothari, S. P.; A. Leone; and C. Wasley. "Performance Matched Discretionary Accrual Measures." Journal of Accounting and Economics, 39 (2005), 163-197.

Krishnan, G., and G. Visvanathan. "Does the SOX Definition of an Accounting Expert Matter? The Association between Audit Committee Directors' Accounting Expertise and Accounting Conservatism." Contemporary Accounting Research, 25 (2008), 827-858.

Linck, J.; J. Netter; and T. Yang. "The Effects and Unintended Consequences of the Sarbanes-Oxley Act on the Supply and Demand for Directors." Review of Financial Studies, 22 (2008), 3287-3328.

Minton, B.; J. Taillard; and R. Williamson. "Do Independence and Financial Expertise of the Board Matter for Risk Taking and Performance?” Working Paper, Ohio State University (2011). 
Moeller, S.; F. Schlingemann; and R. Stulz. "Firm Size and the Gains from Acquisitions." Journal of Financial Economics, 73 (2004), 201-228.

Morck, R.; A. Shleifer; and R. Vishny. "Do Managerial Objectives Drive Bad Acquisitions?" Journal of Finance, 45 (1990), 31-48.

Parrino, R. "CEO Turnover and Outside Succession: A Cross-Sectional Analysis." Journal of Financial Economics, 46 (1997), 165-197.

Parrino, R.; R. Sias; and L. Starks. "Voting with Their Feet: Institutional Ownership Changes around Forced CEO Turnover.” Journal of Financial Economics, 68 (2003), 3-46.

Perry, S., and T. Williams. "Earnings Management Preceding Management Buyout Offers." Journal of Accounting and Economics, 18 (1994), 157-179.

Petersen, M. "Estimating Standard Errors in Finance Panel Data Sets: Comparing Approaches." Review of Financial Studies, 22 (2009), 435-480.

Srinivasan, S. "Consequences of Financial Reporting Failure for Outside Directors: Evidence from Accounting Restatements and Audit Committee Members." Journal of Accounting Research, 43 (2005), 291-334.

Weisbach, M. “Outside Directors and CEO Turnover." Journal of Financial Economics, 20 (1988), 431-460.

White, H. "A Heteroskedasticity-Consistent Covariance Matrix Estimator and a Direct Test for Heteroskedasticity.” Econometrica, 48 (1980), 817-838. 